\title{
Responses to Cell Loss Become Restricted as the Supporting Cells in Mammalian Vestibular Organs Grow Thick Junctional Actin Bands That Develop High Stability
}

\author{
Joseph C. Burns ${ }^{1,2}$ and Jeffrey T. Corwin ${ }^{1,3}$ \\ Departments of ${ }^{1}$ Neuroscience, ${ }^{2}$ Biomedical Engineering, and ${ }^{3}$ Cell Biology, University of Virginia School of Medicine, Charlottesville, Virginia 22908
}

\begin{abstract}
Sensory hair cell (HC) loss is a major cause of permanent hearing and balance impairments for humans and other mammals. Yet, fish, amphibians, reptiles, and birds readily replace HCs and recover from such sensory deficits. It is unknown what prevents replacement in mammals, but cell replacement capacity declines contemporaneously with massive postnatal thickening of F-actin bands at the junctions between vestibular supporting cells (SCs). In non-mammals, SCs can give rise to regenerated HCs, and the bands remain thin even in adults. Here we investigated the stability of the F-actin bands between SCs in ears from chickens and mice and Madin-Darby canine kidney cells. Pharmacological experiments and fluorescence recovery after photobleaching (FRAP) of SC junctions in utricles from mice that express a $\gamma$-actin-GFP fusion protein showed that the thickening F-actin bands develop increased resistance to depolymerization and exceptional stability that parallels a sharp decline in the cell replacement capacity of the maturing mammalian ear. The FRAP recovery rate and the mobile fraction of $\gamma$-actin-GFP both decreased as the bands thickened with age and became highly stabilized. In utricles from neonatal mice, time-lapse recordings in the vicinity of dying HCs showed that numerous SCs change shape and organize multicellular actin purse strings that reseal the epithelium. In contrast, adult SCs appeared resistant to deformation, with resealing responses limited to just a few neighboring SCs that did not form purse strings. The exceptional stability of the uniquely thick F-actin bands at the junctions of mature SCs may play an important role in restricting dynamic repair responses in mammalian vestibular epithelia.
\end{abstract}

Key words: actin; hair cell; inner ear; junction; regeneration; vestibular

\section{Introduction}

Sensory hair cell (HC) losses lead to permanent hearing and balance impairments in humans and other mammals, but epithelial supporting cells (SCs) in the ears of non-mammalian vertebrates respond to $\mathrm{HC}$ loss by resealing the epithelium and giving rise to replacement HCs that quickly restore those senses (Brigande and Heller, 2009; Warchol, 2011; Burns and Corwin, 2013). What prevents mammalian SCs from regenerating HCs? The cause is unknown, but recent evidence has shown that the intercellular junctions of SCs in mammalian and non-mammalian ears differ in ways that are strongly correlated with their contrasting regeneration responses (Burns et al., 2008, 2013; Collado et al., 2011b).

Auditory and vestibular epithelia are mosaics of HCs and SCs, with the latter surrounding each $\mathrm{HC}$ on all sides and forming

\footnotetext{
Received Oct. 10, 2013; revised Dec. 5, 2013; accepted Dec. 23, 2013.

Author contributions: J.C.B. and J.T.C. designed research; J.C.B. performed research; J.C.B. and J.T.C. analyzed data; J.C.B. and J.T.C. wrote the paper.

This work was supported by National Institutes of Health Grants F31-DC010519 (J.C.B.) and R01-DC000200 (J.T.C.). We thank J. R. Bamburg, L. S. Minamide, C. W. Pak, A. E. Shaw, B. W. Bernstein, T. M. Coate, and M. W. Kelley for providing reagents and technical assistance. We also thank M. W. Kelley, M. Kelly, and C. W. Sipe for critical feedback on this manuscript.

The authors declare no competing financial interests.

Correspondence should be addressed to Jeffrey T. Corwin, Department of Neuroscience, University of Virginia Medical School, 409 Lane Road, Charlottesville, VA 22908. E-mail: jtc2k@virginia.edu.

DOI:10.1523/JNEUROSCI.4355-13.2014

Copyright $\odot 2014$ the authors $\quad 0270-6474 / 14 / 341998-14 \$ 15.00 / 0$
}

apical intercellular junctions at SC-SC and SC-HC interfaces (Groves and Fekete, 2012; Deans, 2013). Sharks, zebrafish, frogs, turtles, and birds continue to produce substantial numbers of HCs throughout life, and, as in other epithelial cells, the junctions between their SCs are lined by thin circumferential bands of filamentous actin (F-actin). Vestibular epithelia in those species also express little or no E-cadherin (Collado et al., 2011b; Burns et al., 2013). At birth, the SC-SC junctions in mice have thin actin bands and express low levels of E-cadherin, but the actin bands grow in thickness and E-cadherin increases as the ears of mice mature postnatally (Burns et al., 2008, 2013; Collado et al., 2011b; Anttonen et al., 2012). Ultimately, F-actin bands grow to fill $\sim 90 \%$ of the apical area of the average utricular SC in adult mice and humans (Burns et al., 2008).

The reinforcement of the junctions occurs contemporaneously with sharp postnatal declines in SC plasticity, SC proliferation, new HC production, and mitotic $\mathrm{HC}$ regeneration (Ruben, 1967; Gu et al., 1997, 2007; Davies et al., 2007; Meyers and Corwin, 2007; Oshima et al., 2007; Lu and Corwin, 2008; Burns et al., 2012a,b; Golub et al., 2012; Kelly et al., 2012; Liu et al., 2012). Intercellular junctions and their actin bands appear to play pivotal roles in regulating growth and renewal in other epithelia, so that cell death and extrusion are matched by cell replacement (Ingber, 2008; Miyoshi and Takai, 2008; Cavey and Lecuit, 2009; Meng and Takeichi, 2009; Boggiano and Fehon, 2012; Guillot 
and Lecuit, 2013). For that reason, we set out to investigate the stability of the actin bands of SCs. Our results show that the F-actin bands in murine SCs become extraordinarily stabilized as they thicken postnatally. By making time-lapse recordings of cells in the vicinity of dying HCs in utricles from young and old mice, we found that the thickening and stabilization that occurs in the maturing ear coincides with reductions in cellular responses and may impede important regenerative processes by limiting the dynamic reorganization of cell junctions and the spread of intraepithelial tension that occurs around dying HCs in younger epithelia.

\section{Materials and Methods}

Animals and dissection of vestibular organs. All animals were handled in accordance with protocols approved by the Animal Care and Use Committee at the University of Virginia. Swiss Webster mice were obtained from Charles River Laboratories. Transgenic mice that express a $\gamma$-actin and green fluorescent protein (GFP) fusion protein were generated in the laboratory of Dr. Andrew Matus (Friedrich Miescher Institute for Biomedical Research, Basil, Switzerland; Fischer et al., 1998, 2000) and were obtained from the Friedrich Miescher Institute for Biomedical Research. Fertilized eggs from White Leghorn chickens were obtained from CBT Farms and were incubated to hatching. Animals of either sex were used for all experiments. For tissue harvest, labyrinths were dissected from temporal bones, vestibular organs were isolated, and the roof and the otoconia were mechanically removed.

Organ and cell culture. Utricles dissected from mice and chickens were adhered nerve-side-down to glass-bottom dishes (Mat-Tek) that we coated with Cell Tak ( $2 \mu \mathrm{l}$ air-dried onto the glass and washed three times with medium; BD Biosciences). Madin-Darby canine kidney (MDCK) epithelial cells were cultured in uncoated glass-bottom dishes and grown to $75 \%$ confluence. Culture medium consisted of DMEM/F-12 with $1 \%$ fetal bovine serum (FBS; Invitrogen), $3 \mu \mathrm{g} / \mathrm{ml}$ BrdU, $0.25 \mu \mathrm{g} / \mathrm{ml}$ Fungizone (Invitrogen), and $10 \mu \mathrm{g} / \mathrm{ml}$ Ciprofloxacin (Bayer). Utricles were cultured at $37^{\circ} \mathrm{C}$ and $5 \% \mathrm{CO}_{2}$. Latrunculin $\mathrm{A}$ (LatA; Calbiochem) and cytochalasin D (CytoD; Sigma-Aldrich) were reconstituted in ethanol and added to the culture medium at the concentrations and for the durations indicated. Neomycin sulfate at $3 \mathrm{~mm}$ (equilibrated to $\mathrm{pH}$ 7.4) was added to the culture medium to kill HCs at the times indicated.

Live/dead cell viability assays were conducted per the instructions of the manufacturer (Invitrogen): $4 \mu \mathrm{M}$ calcein AM and $4 \mu \mathrm{M}$ ethidium homodimer-1 (EthD-1) were prepared in fresh PBS, and utricles were incubated at $37^{\circ} \mathrm{C}$ and $5 \% \mathrm{CO}_{2}$ for $30 \mathrm{~min}$ before imaging on a Zeiss LSM 510 confocal microscope.

Adenoviral infection. Adenoviruses encoding red fluorescent protein (RFP) and wild-type human cofilin under separate cytomegalovirus (CMV) promoters or RFP alone under a CMV promoter were generous gifts from Dr. J. Bamburg (Colorado State University, Fort Collins, CO). For transfection with adenoviral vectors, utricles were equilibrated to the culture conditions for $24 \mathrm{~h}$ in $100 \mu \mathrm{l}$ of medium. The FBS-containing medium was then washed out with five rinses of DMEM/F-12, and the utricles were incubated with concentrated adenovirus $\left(1 \times 10^{8} \mathrm{IU} / \mathrm{ml}\right.$ in $100 \mu \mathrm{l}$ of DMEM/F-12) for $24 \mathrm{~h}$. The adenovirus was subsequently washed out, and utricles were incubated in $2 \mathrm{ml}$ of culture medium for the remainder of the culture period.

Immunocytochemistry. Utricles, freshly dissected and cultured, were fixed in $4 \%$ paraformaldehyde in PBS overnight at $4^{\circ} \mathrm{C}$. Specimens labeled with phalloidin alone were then incubated for $1 \mathrm{~h}$ at room temperature (RT) in PBS containing $0.2 \%$ Triton X-100 (PBS-T) and Alexa Fluor 488 phalloidin ( $5 \mathrm{U} / \mathrm{ml}$; Invitrogen). Some samples were incubated with the following primary antibodies in PBS-T with 2\% NGS overnight: rat anti-E-cadherin (to detect intercellular junctions; 1:200; Invitrogen) or mouse anti-occludin (to detect intercellular junctions; 1:200; Invitrogen). Primary antibodies were then washed out with PBS-T, and the specimens were incubated with Alexa Fluor-conjugated phalloidin, Alexa Fluor-conjugated secondary IgG (heavy and light chains; $2 \mathrm{mg} / \mathrm{ml}$; Invitrogen), and $1 \mu \mathrm{M}$ TO-PRO-3 iodide (Invitrogen) for $3 \mathrm{~h}$ at RT. After washes in PBS, the specimens were mounted in Slow Fade (Invitrogen)
Table 1. Coefficient values for two-phase exponential curve fits of FRAP data

\begin{tabular}{lllcccc}
\hline & \multicolumn{6}{l}{$F_{\text {total }}=F_{\max 1}\left(1-e^{-k_{1} t}\right)+F_{\max 2}\left(1-e^{-k_{2} t}\right)$} \\
\cline { 2 - 7 } Age & $F_{\max 1}$ & $k_{1}$ & $t_{\text {half1 }}$ & $F_{\max 2}$ & $k_{2}$ & $t_{\text {half2 }}$ \\
\hline P0 & 0.19 & 0.16 & 4.2 & 0.59 & 0.03 & 25.7 \\
P8 & 0.16 & 0.55 & 1.3 & 0.52 & 0.01 & 63.6 \\
$>$ P20 & 0.18 & 1.3 & 0.5 & 0.21 & 0.01 & 64.1
\end{tabular}

Fits of two-phase exponential equations to the FRAP data show that the estimated sizes of the immobile fraction and the rate constants of the slow component of the fluorescence recovery both increase with age. Total fluorescence recovery $\left(F_{\text {tota }}\right)$ over time in minutes $(t)$ is the summation of fast and slow exponentials. The maximum recovery and rate constants of the fast and slow exponentials are listed as $F_{\max 1} F_{\max 22^{\prime}}$ and $k_{1}, k_{2^{\prime}}$ respectively. The size of the immobile fraction is estimated by $1-\left(F_{\max 1}+F_{\max 2}\right)$. The half-lives of the fast and slow exponentials $\left(t_{\text {half } 1}\right.$ and $t_{\text {half }}$ ) are given by $0.69 / k$. The fast component of the recovery has been attributed to the diffusion of actin monomers into the photobleached region, whereas the slow component likely represents the assembly, treadmilling, and/or mobilization of actin filaments (Amato and Taylor, 1986; McGrath et al., 1998a,b; Campbell and Knight, 2007).

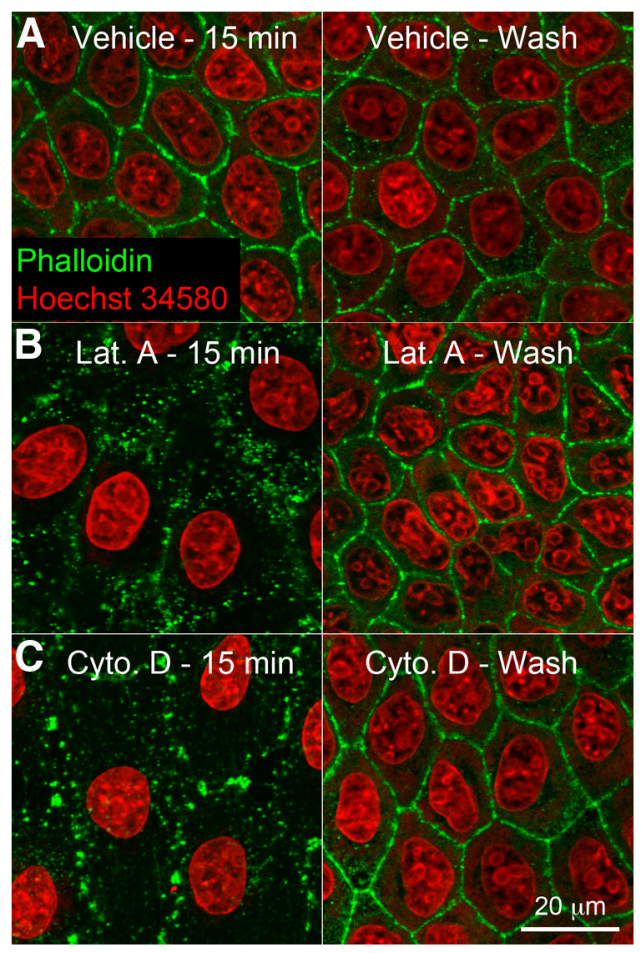

Figure 1. LatA and CytoD rapidly and reversibly disassemble circumferential F-actin bands in MDCK epithelial cells. $\boldsymbol{A}-\boldsymbol{C}$, Confocal images of MDCK cells treated with vehicle, $5 \mu \mathrm{m}$ LatA, or $100 \mathrm{~nm}$ CytoD for $15 \mathrm{~min}$ (left), followed by washout and an additional $3 \mathrm{~h}$ of culture (right) before fixation and labeling of F-actin with fluorescent phalloidin (green) and nuclear DNA with Hoechst 34580 (red). Residual, phalloidin-labeled puncta remain in proximity to the disassembled junctional F-actin after LatA and CytoD treatments, similar to pools of latrunculin-resistant F-actin that have been reported previously (Rosin-Arbesfeld et al., 2001).

and analyzed using Zeiss LSM 510, 700, or 710 laser scanning confocal microscopes.

Time-lapse microscopy and fluorescence recovery after photobleaching experiments. Utricles dissected from P0, P8, and $>$ P2 2 -actin-GFP mice were transferred to POC-R chambers (Pecon) containing $2 \mathrm{ml}$ of DMEM/F-12 with $1 \%$ FBS. To restrict movement during imaging, utricles were stabilized under a pair of thin glass fibers glued to a number 1.5 coverslip (sensory epithelium facing the coverslip; Stauffer and Holt, 2007). The imaging chambers were then secured in an incubation unit (Pecon) mounted on the stage of a Zeiss LSM 510 microscope and were maintained at $37^{\circ} \mathrm{C}, 5 \% \mathrm{CO}_{2}$ and $95 \%$ humidity. For time-lapse recordings of LatA treatments and $\mathrm{HC}$ death events, $5 \mu \mathrm{m}$ LatA or $3 \mathrm{~mm}$ neomycin sulfate were added to the culture medium, and $30-\mu \mathrm{m}$-deep $z$-stacks were captured for the periods indicated.

For fluorescence recovery after photobleaching (FRAP) experiments, specified regions of GFP fluorescence in the circumferential bands of SCs 


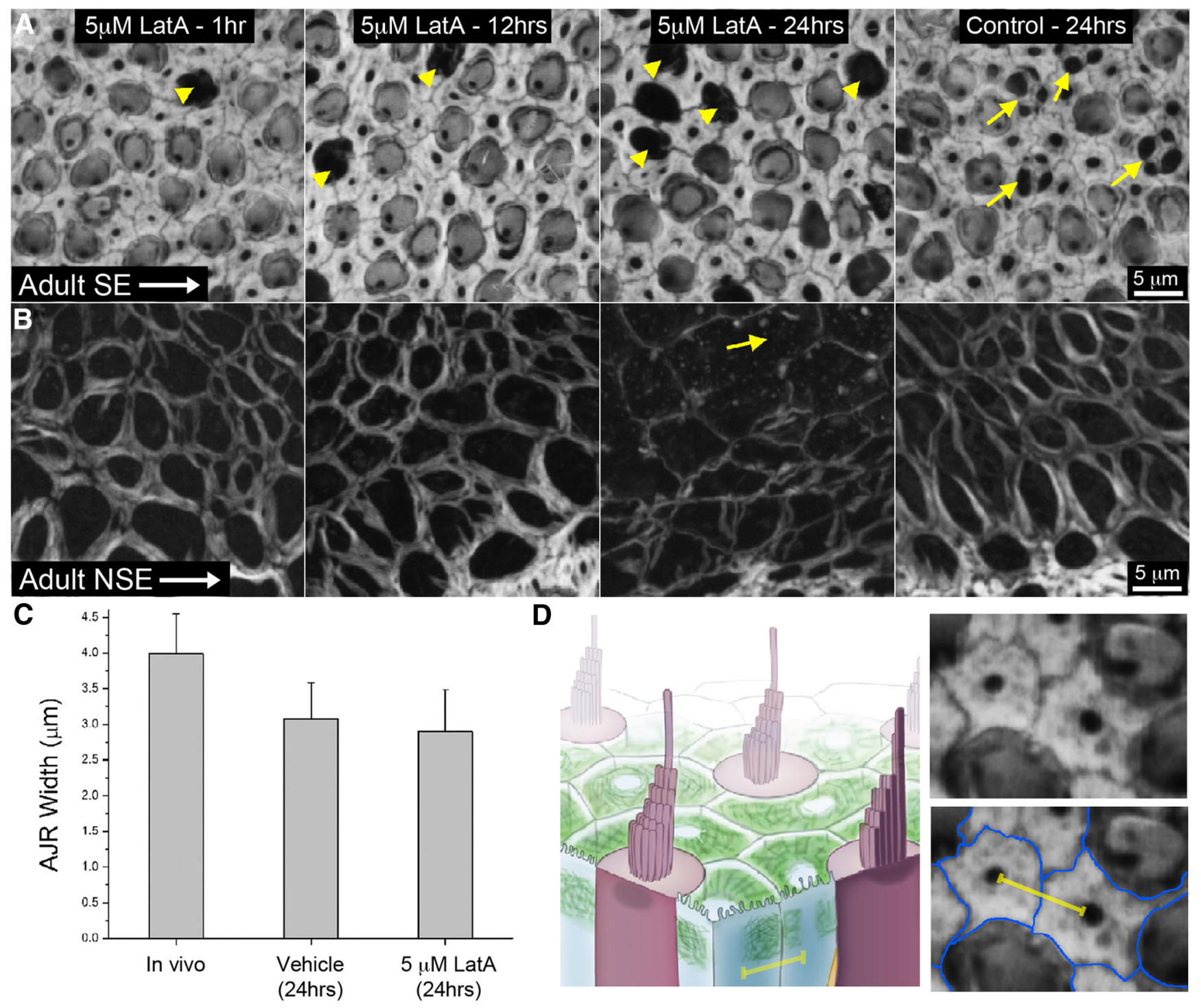

Figure 2. LatA treatments did not produce detectable changes in the size of the reinforced F-actin bands in adult mouse utricles. $A$, Confocal images of sensory epithelia (SE) that were cultured with $5 \mu \mathrm{m}$ LatA or vehicle control for 1, 12, or $24 \mathrm{~h}$ and then fixed and labeled with fluorescent phalloidin to visualize F-actin. Arrowheads indicate regions of $\mathrm{HC}$ loss, which SCs did not enter. Arrows indicate regions of $\mathrm{HC}$ loss in which $\mathrm{SC}$ extended processes and began to fill in the vacancies left by the dying $\mathrm{HCS}$. B, Confocal images of the nonsensory epithelium (NSE) surrounding the sensory epithelia in the same treated and control utricles shown in $A$. Partial band disassembly can be seen in the NSE of a utricle treated for $24 \mathrm{~h}$ (yellow arrow). C, Graph shows a quantitative comparison among AJR widths in SCs of adult mouse utricles fixed in vivo (Burns et al., 2008) and cultured utricles fixed after $24 \mathrm{~h}$ treatments with $5 \mu \mathrm{m}$ LatA or vehicle alone. D, Left, The illustration depicts apical structures in the mouse utricular sensory epithelium, with HCs in magenta and SCs in blue. On average, the circumferential F-actin bands of SCs (green) occupy $\sim 89 \%$ of the apical cytoplasm in SCS in adult utricles. To look for subtle changes in the size of the bands in the treated utricles, we measured the width of AJRs, which comprise the intercellular junction and circumferential F-actin bands in the two SCs that bracket it (Burns et al., 2008). The yellow bar delineates the width of an AJR. Right, A single confocal slice near the apical surface of a phalloidin-labeled adult mouse utricle shows the AJR. The intercellular junctions appear as thin dark lines running between the edges of the phalloidin-labeled bands that are located near the borders of adjacent SCS. The intercellular junctions are highlighted in blue on the bottom image.

were photobleached with 300 short-duration $(3.3 \mathrm{~ms})$ pulses of the 488 $\mathrm{nm}$ argon laser ( $95 \%$ power) focused through a $63 \times / 1.4$ numerical aperture oil-immersion objective. For 25 min before photobleaching, a single confocal image at the same focal plane was captured every $5 \mathrm{~min}$, and a $30-\mu \mathrm{m}$-deep $z$-stack with a $z$-section thickness of $0.5 \mu \mathrm{m}$ was captured every $10 \mathrm{~min}$ for $3 \mathrm{~h}$ immediately after the last bleach pulse. Axiovision software (Zeiss) was used to perform an affine transformation on the acquired $z$-stacks to correct for tissue drift in $x, y$, and $z$. Images were then analyzed for fluorescence recovery within the focal plane of the bleach region according to the methods of Phair et al. (2004). Briefly, normalized fluorescence intensity was calculated for background subtracted images using the following equation: $I=T_{0} I_{t} / T_{t} I_{0}$, where $T_{0}$ is the total prebleach intensity in the entire band, $T_{t}$ is the total band intensity at time point $t, I_{0}$ is the total prebleach intensity in the photobleached region, and $I_{t}$ is the total intensity in the bleach region at time point $t$.
One-phase and two-phase exponential association equations were fit to the FRAP data using GraphPad Prism software, and the immobile fraction and half-lives of recovery were calculated as described (Table 1; Lippincott-Schwartz et al., 2001, 2003; Campbell and Knight, 2007; Zheng et al., 2011).

Using a custom program written in MATLAB based on equations from Song et al. (1995), the images shown have been corrected for the overall bleaching that was attributable to acquisition. Affine transformations and background correction were also performed for time-lapse recordings of LatA treatments and $\mathrm{HC}$ death events. After taking quantitative measurements, we sequentially processed movies with smooth, sharpen, and despeckle filters in NIH ImageJ.

Measurement of apical junction regions and intercellular junction widths and statistics. To measure the widths of the apical junction regions (AJRs), which extend across the intercellular junction between two epi- 


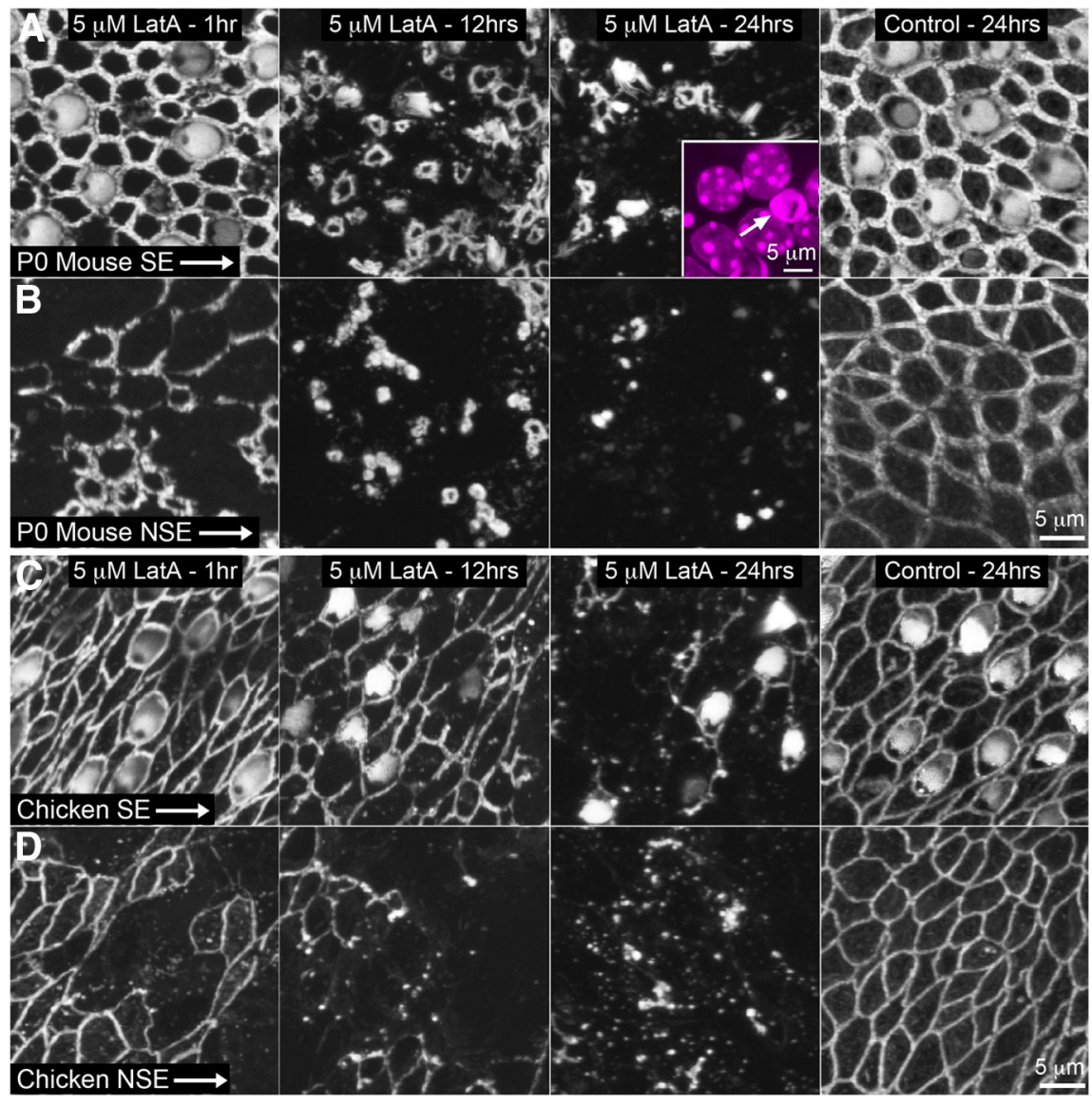

Figure 3. LatA treatments disassemble the circumferential $F$-actin bands in utricles from newborn mice and hatchling chickens. $A, B$, Confocal images of the sensory epithelium (SE) and nonsensory epithelium (NSE) from P0 mouse utricles that were cultured with $5 \mu \mathrm{m}$ LatA or vehicle control for 1, 12, or $24 \mathrm{~h}$ and then fixed and labeled with phalloidin. Inset in $A$ shows T0-PRO-3 iodide (magenta) labeling of SC nuclei persisting in a region of extensive actin band disassembly. One pyknotic nucleus is apparent (arrow), but the surrounding nuclei appear normal. $C, D$, Confocal images of PO chicken utricles at the same time points after the same treatments.

thelial cells and the F-actin bands on the two sides of that junction (Burns et al., 2008), we captured the intensity versus distance profiles for lines that we drew perpendicular to individual junctions using NIH ImageJ. The forward difference of the intensity profiles, which is an approximation of the derivative, was calculated for each line. The widths of the intensity curves for phalloidin fluorescence were then determined by measuring the distance between the local maxima and minima on the forward difference plot. This provided an unbiased measure spanning the two outer edges of each AJR. Measurements of the widths of intercellular junction regions presented in Figure $9 E$ were measured in the same way.

Tests for statistical significance were conducted using OriginPro 7.5 (OriginLab) or GraphPad Prism 8.0 (GraphPad Software). All bar graphs display mean \pm SEM.

\section{Results}

LatA treatments caused minimal changes in the thick actin bands

To test whether the sequestration of actin monomers would depolymerize the actin filaments that make up the thickened circumferential bands in mature mammalian SCs, we cultured utricles from adult mice (older than P80) and treated them with the toxin LatA for up to $24 \mathrm{~h}$. In other epithelia, the range of concentrations we investigated $(20 \mathrm{nM}$ to $5 \mu \mathrm{M})$ can cause the complete disassembly of actin bands and adherens junctions within minutes to hours (Fig. 1A, B; Yamada et al., 2004; Ivanov et al., 2005; Cavey et al., 2008). Remarkably, the bands in the
LatA-treated SCs remained intact, even after $24 \mathrm{~h}$ treatments at the highest concentration (Fig. 2A,C,D). Contrasting with those results, identical $24 \mathrm{~h}$ treatments with $5 \mu \mathrm{M}$ LatA resulted in partial disruption of $\mathrm{F}$-actin bands in cells within the nonsensory epithelium that extends out from the edge of the sensory macula (Fig. 2B, arrow). Equivalent treatments completely disassembled F-actin bands in MDCK epithelial cells that had formed polarized epithelia, and that effect was reversible as shown by the reformation of the bands after washout (Fig. $1 A, B$ ).

To determine whether resistance to LatA treatments is specific to mammalian SCs that have matured and grown thick junctional actin bands, we cultured utricles from newborn (P0) mice and newly hatched (P0) chicks with $5 \mu \mathrm{M}$ LatA and fixed groups of these cultures at 1,12 , and $24 \mathrm{~h}$. In sharp contrast to the LatA resistance of the F-actin bands in the adult mouse SCs, the actin bands of the SCs in the age-matched utricles from the young mice and chicks displayed extensive depletion of junctional F-actin within 1-12 $\mathrm{h}$ (Figs. $3 A, C)$. In addition, LatAmediated thinning of the F-actin bands progressed even more quickly in the surrounding nonsensory epithelia of those utricles (Fig. $3 B, D$ ). In fact, the loss of phalloidin labeling in the P0 mouse utricles was so complete that we needed to use TO-PRO-3 iodide labeling to confirm that nuclei were present in intact cells after the extensive actin band disassembly (Fig. 3A, inset). Use of a live/dead assay confirmed that most cells were alive (Fig. 4). Because the LatA treatments used here readily disrupt the circumferential F-actin bands in less differentiated SCs and other types of epithelial cells but failed to cause measurable differences in the dimensions of the thick F-actin bands in vestibular SCs from adult mice, we decided to determine whether the resistance to depolymerization was specific to LatA or whether the bands would be resistant to other agents that are able to disrupt F-actin.

CytoD reduces the thickness of reinforced F-actin bands CytoD causes rapid disruption of F-actin bands in epithelial cells, so we investigated whether it would disrupt the thickened F-actin bands in utricles from adult mouse utricles (Fig. 1 A, C; Madara et al., 1986; Stevenson and Begg, 1994; Quinlan and Hyatt, 1999; Vasioukhin et al., 2000). SCs in adult mouse utricles did not show qualitative changes in the morphology of the actin bands after culturing with $100 \mathrm{~nm}$ CytoD for $1 \mathrm{~h}$, so we extended the treatment duration to $24 \mathrm{~h}$, which resulted in marked reductions in thickness (Fig. 5A). Similar results were observed in response to other concentrations ( $10 \mathrm{~nm}$ or $2 \mu \mathrm{M}$ ) of CytoD after $24 \mathrm{~h}$ (Fig. $5 B$ ). We quantified the changes in the bands by measuring the width of $>200$ AJRs (as defined in Fig. 2D) in utricles treated with $100 \mathrm{~nm}$ CytoD or vehicle control for $24 \mathrm{~h}$. The measurements showed a $33 \pm 3 \%$ reduction in AJR width in the CytoD-treated utricles compared with controls $(n=4$ utricles; $p=0.0001$, Student's $t$ test; Fig. $5 E)$. When we 
extended the treatment to $72 \mathrm{~h}$ in $100 \mathrm{nM}$ CytoD, we observed no additional reduction in band thickness (Fig. 5B). To determine whether this actin band thinning was reversible, we rinsed treated utricles in control medium for $24 \mathrm{~h}$ to wash out CytoD and then cultured them for an additional $120 \mathrm{~h}$. The washout and extended culture period did not cause a reversal of the major thinning effect, but the bands regained continuity and showed evidence of reorganization or reformation (Fig. 5B).

To rule out the possibility that the CytoD was interfering with binding of the fluorophore-conjugated phalloidin that we used to visualize and measure F-actin, we repeated these experiments using utricles from mice that carry a widely expressed transgene encoding a $\gamma$-actinGFP fusion protein (Fischer et al., 1998, 2000). Utricles from these mice exhibit intense fluorescence in structures that are F-actin rich, in both living and fixed tissues (Fig. 5C). Twenty-four hour treatments with $100 \mathrm{~nm}$ CytoD resulted in comparable AJR width reductions whether width was assessed via $\gamma$-actinGFP labeling or fluorophore-conjugated phalloidin labeling ( $n=4$ utricles; Fig. $5 D, E)$, confirming that long-duration treatments with $100 \mathrm{~nm}$ CytoD reduce the thickness of the reinforced F-actin bands present at the junctions between SCs in adult mouse utricles.

In contrast to the results of the LatA experiments, when we treated utricles from P0 mice and chickens with CytoD, minimal changes were observed to the width of the already thin bands of junctional actin in their SCs and non-sensory epithelial cells. The changes in those bands were limited to fraying and a loss of edge continuity that was noticeable when compared with controls (Fig. 6A, yellow arrows, $B$, insets). Thus, thick actin bands in SCs of adult mice are essentially unaffected by LatA treatments that cause massive depolymerization of the thin actin bands in the SCs of young mice and chickens, but those thick bands show substantial thinning when cultured with CytoD at concentrations and durations that cause minimal effects on the already thin bands that are present at the junctions between the SCs of neonatal mice and newly hatched chickens. Together, the results of the LatA and CytoD experiments suggest that the thick circumferential bands at the junctions of SCs in adult mouse utricles comprise at least two different zones of actin filament organization or populations of actin filaments that differ. The results also show that the actin bands at the junctions between mammalian SCs become globally stabilized as they grow to considerable thickness after birth.

\section{Cofilin expression disrupts circumferential actin bands in SCs}

Because LatA and CytoD experiments were limited to depolymerization that could be caused by inhibition of monomer addition, we decided to investigate how the apparently stabilized bands would be affected by treatments that cause severing of actin filaments. For this, we used adenoviral vectors to overexpress cofilin/RFP under the control of separate CMV promoters in vitro. Cofilin severs filaments at physiological levels, increases the rate of monomer loss from the pointed end, and competes with other proteins for binding sites on F-actin, so it has the potential to destabilize reinforced actin bands even in the presence of specialized capping and stabilizing proteins (Bamburg and Wiggan, 2002; Sarmiere and Bamburg, 2004). An adenovirus that encoded RFP alone served as a control. By $16 \mathrm{~h}$ after infection, we detected red fluorescence in some SCs, and, in other specimens that we fixed at $96 \mathrm{~h}$, phalloidin-labeled actin bands were disrupted or absent from a portion of the cofilin/RFP-expressing cells (Fig. $7 A$ ). All uninfected cells and the cells that were infected with RFP alone had band morphologies similar to SCs in uninfected control cultures ( $n=4$ utricles; Fig. $7 B$ ).

Because cofilin is known to compete with phalloidin for binding to actin filaments (Nishida et al., 1987), we set up an experiment to control for that confounding possibility. For this, we used cofilin/RFP adenovirus to infect utricles from $\gamma$-actin-GFP mice in which phalloidin fluorescence would not be the sole label used to determine whether the changes in band morphology we 

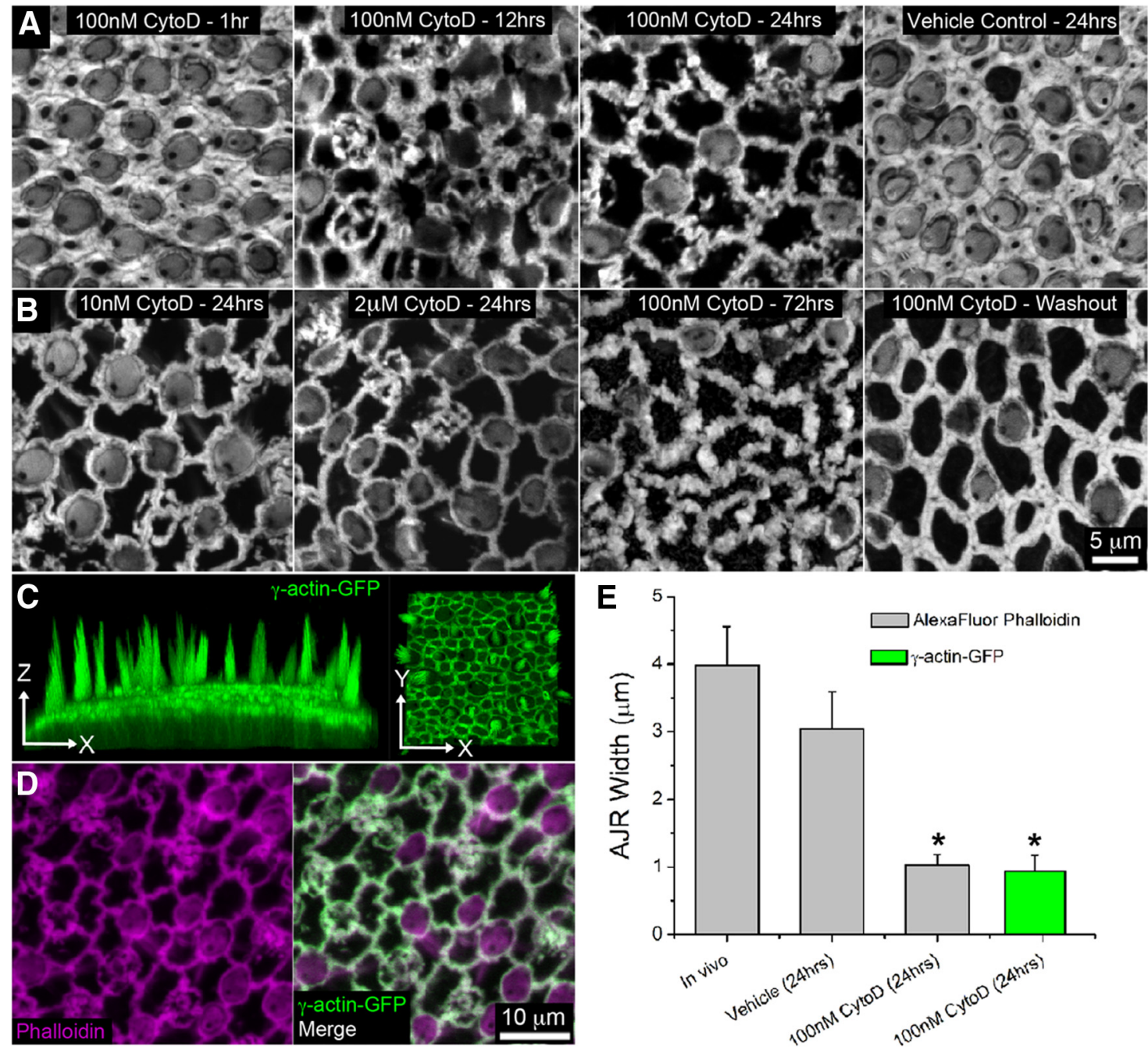

Figure 5. CytoD thins the wide actin bands at the junctions of SCs in adult mice. $A$, Confocal images of adult mouse utricles that were cultured with $100 \mathrm{~nm} C y t_{0} D$ or vehicle alone for $1-24 \mathrm{~h}$ and then fixed and labeled with fluorescent phalloidin. $\boldsymbol{B}$, Images of adult mouse utricles that were cultured with different concentrations of $\mathrm{CytoD}$, or for different durations, then fixed and labeled with phalloidin. C, Confocal 3D renderings of live utricles from $\gamma$-actin-GFP mice. F-actin-rich structures, such as hair bundles ( $x-z$ view parallel to the long axis of the $\mathrm{HCs}$ ) and circumferential actin bands ( $x$-y view near the apical surface of the sensory epithelium), exhibit intense $\gamma$-actin-GFP (green) fluorescence. D, Utricles from $\gamma$-actin-GFP mice imaged after a $24 \mathrm{~h}$ treatment with $100 \mathrm{~nm}$ CytoD, fixation, and colabeling with fluorescent phalloidin (magenta). $E$, Graph shows the AJR widths measured from fluorescent phalloidin labeling of F-actin (gray bars) in adult mouse utricles in vivo (Burns et al., 2008) and after a $24 \mathrm{~h}$ treatment with vehicle alone or $100 \mathrm{~nm}$ CytoD. Note the agreement between widths measured from fluorescent phalloidin and from the fluorescence of $\gamma$-actin-GFP (green bars). Asterisks indicate a significant difference between the two measures for the treated samples and the vehicle control ( $n=4$ utricles; $p=0.0001$; one-way ANOVA with Tukey's multiple comparisons test).

observed were artifactual. In these cofilin/RFP-expressing cells, both $\gamma$-actin-GFP labeling and phalloidin labeling showed junctional F-actin disruption (Fig. 7A), which contrasted with the $\gamma$-actin-GFP/phalloidin-labeled bands that remained intact in control utricles that were infected with the RFP adenovirus $(n=$ 4 utricles; Fig. $7 B)$.

The reinforced F-actin bands are highly stabilized

To more directly assess the stability of the bands, we conducted FRAP experiments, which would give a readout of the mobility of the actin that makes up the junctional bands in the SCs of adult and young mice. When we photobleached $1 \times 1 \mu \mathrm{m}$ regions of the circumferential bands in the SCs of P0, P8, and >P20 $\gamma$-actin-GFP mice, we observed that the rate and the magnitude of the normalized recovery of GFP fluorescence declined progressively with age ( $n=15-17$ measurements from 4 utricles each; Fig. 8; Movie 1). FRAP of fluorescently tagged actin has been accurately modeled for bundled filaments using two-phase exponential equations (Amato and Taylor, 1986; McGrath et al., 1998a,b; Campbell and Knight, 2007). Our FRAP data were fit by a twophase exponential equation with $r^{2}>0.99$ at all ages and that showed significantly improved fitting over a one-phase exponential. Calculating the maximum recovery levels for the curve fits revealed that $\gamma$-actin-GFP becomes increasingly immobilized within the circumferential bands as mice mature from P0 to adulthood (fraction of immobilized $\gamma$-actin-GFP: P0, $22.1 \pm$ 9.8\%; P8, 32.2 $\pm 1.5 \%$; > P20, $60.9 \pm 0.8 \%$; Table 1). In addition, the half-life of the slower-recovering component of the twophase exponential was 2.5 times longer in P8 and >P20 mouse utricles than it was in the P0 mouse utricles (half-life of slow recovery: P0, $25.7 \mathrm{~min}$; P8, $63.6 \mathrm{~min}$; > P20, $64.1 \mathrm{~min}$; Table 1). For comparison, FRAP measurements that have been made in stress fibers within cultured fibroblasts, endothelial cells, and chondrocytes and the highly bundled F-actin structures in the lamellipodia of cells derived from neuroblastoma have shown maximal fluorescence recoveries between 1 and $4 \mathrm{~min}$ 


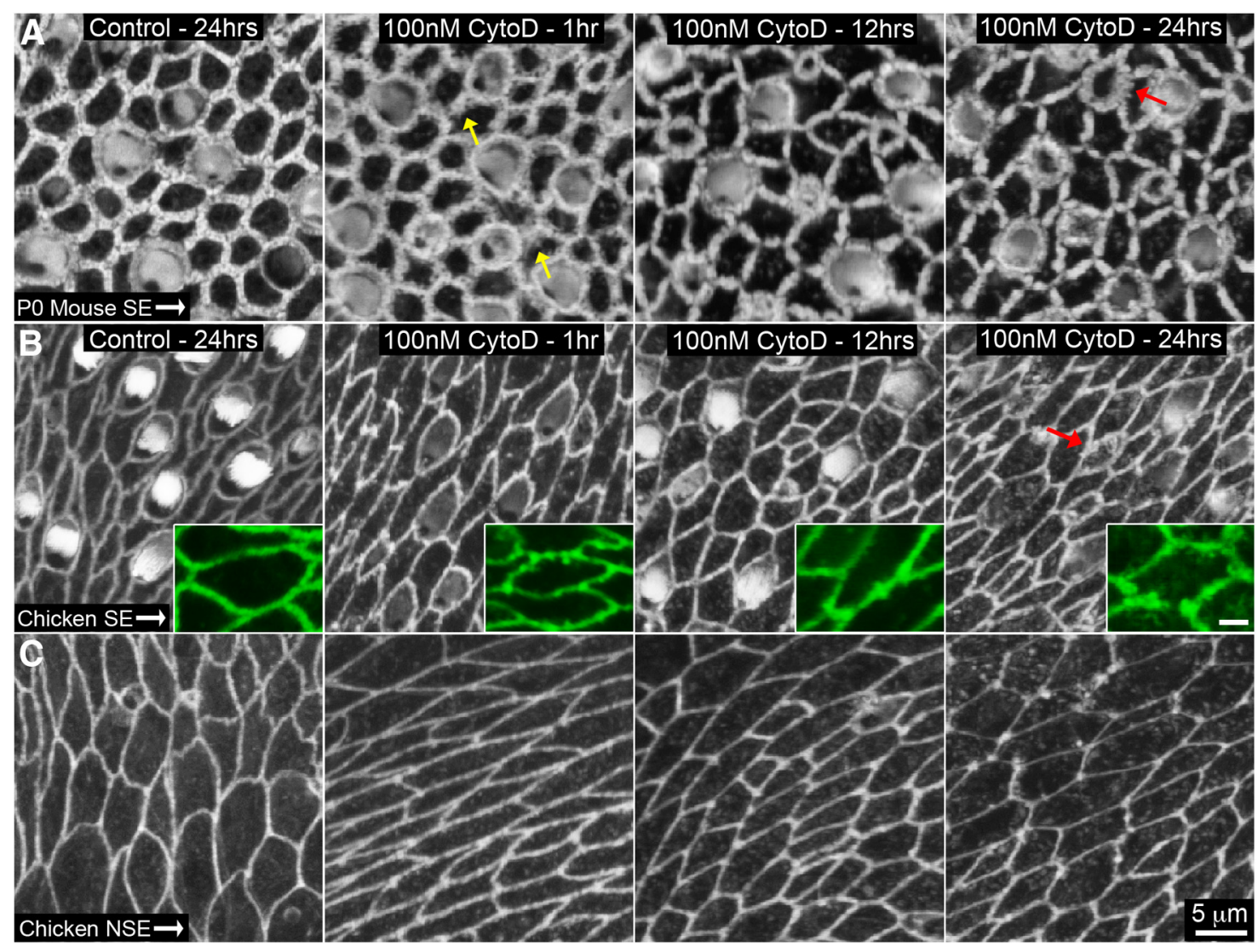

Figure 6. Treatment with CytoD causes the circumferential bands in utricles from newborn mice and young chickens to appear frayed, but reductions in their widths were minimal. $A$, Confocal images of the sensory epithelium (SE) in P0 mouse utricles that were cultured with $100 \mathrm{~nm}$ CytoD or vehicle alone for 1, 12, or $24 \mathrm{~h}$ and then fixed and labeled with phalloidin. Yellow arrows point to frayed bands in the CytoD-treated utricles, and red arrows point to regions of HC loss, which SCs did not enter. For comparison, see Figure 10C, which shows a region in which an $\mathrm{HC}$ died and SCs entered the space it had occupied. $B, C$, Images showing that the same treatments cause only minimal changes in thickness of the narrow F-actin bands in SCs from the sensory epithelium in chicken utricles (B), as well as in the cells in their nonsensory epithelium (NSE) (C). Insets show the contrast between the noticeable fraying of the bands in treated utricles and the controls. Scale bar (in insets), $2 \mu \mathrm{m}$.

(Amato and Taylor, 1986; McGrath et al., 1998a; Mallavarapu and Mitchison, 1999; Campbell and Knight, 2007). The large immobile fraction we observed is more similar to published FRAP measurements for $\beta$-actin-GFP localized in the highly bundled paracrystaline arrays that stiffen $\mathrm{HC}$ stereocilia, which showed little to no recovery for up to $7 \mathrm{~d}$ (Zhang et al., 2012).

The large fractions of immobilized protein and the slower time courses of fluorescence recovery measured in our experiments are consistent with increased actin network stability and reduced rates of monomer exchange at the ends of actin filaments (Amato and Taylor, 1986; Tardy et al., 1995; McGrath et al., 1998a; Campbell and Knight, 2007). Also, the age-related decrease in the maximal percentage and rate of fluorescence recovery that we measured in the circumferential bands at SC-SC junctions shows that filament stability increases in parallel with the age-related accumulation of F-actin that thickens those bands.

\section{Near the junctions, the filaments are less stable}

In the FRAP measurements we made in the utricles from mice that were $>$ P20, we observed a line of intense fluorescence recovery that developed early in the recovery period in close proximity to the intercellular junction. The localized recovery at that site suggested that there might be regional differences in the stability of F-actin in various parts of the circumferential bands. To assess the magnitude and reproducibility of this recovery, we conducted linear FRAP experiments in which we photobleached a 1-pixelwide line that stretched across the entire AJR (i.e., from the center of the apical cytoplasm in one SC to the center of its neighbor). In these experiments, the first detectable recovery of fluorescence always appeared near the center of the bleached region (Fig. 9A; Movie 1). To improve the signal-to-noise ratio, we centered and averaged the intensity profiles from the bleach regions of $10 \mathrm{AJRs}$ and plotted the linear sequence of fluorescence values measured at recovery times of $1 \mathrm{~s}, 1.5 \mathrm{~h}$, and $3 \mathrm{~h}$. The resulting curves describe the growth of a single peak with a maximum fluorescence value that increased to $58.6 \pm 3.5 \%$ of the prebleached level (Fig. 9B). This peak value was $19.5 \%$ greater than the maximum recovery in the $1 \times 1 \mu \mathrm{m}$ square FRAP regions we had assessed in the $>$ P20 mouse utricles but was $19.3 \%$ less than the peak value measured in the $1 \times 1 \mu \mathrm{m}$ square regions of the P0 mouse utricles.

To determine the spatial relationship between the peaks of early recovery and the intercellular junctions, we fixed a subset of the utricles from the linear FRAP experiments and immunolabeled them with an E-cadherin antibody. The E-cadherin labeling showed that the thin lines of greatest fluorescence recovery were centered on intercellular junctions between SCs (Fig. 9C). After finding that, we reexamined LatA-treated utricles from neonatal and adult mice and noticed that the filaments in the region nearest to the junction also showed the greatest susceptibility 

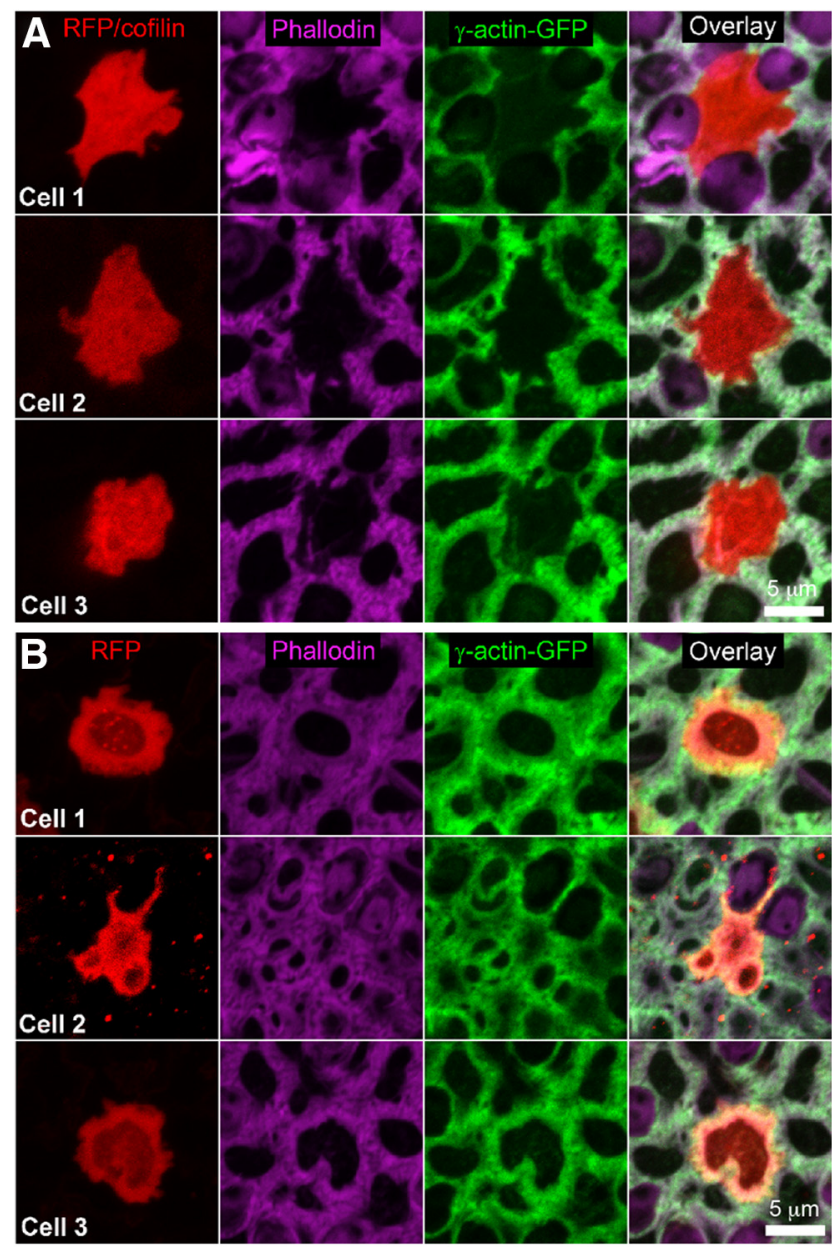

Figure 7. Expressing cofilin in utricles from $\gamma$-actin-GFP mice removes circumferential F-actin bands from SCs. A, Confocal images of example cells in three different utricles from adult $\gamma$-actin-GFP mice that were cultured for $96 \mathrm{~h}$ after infection with adenovirus encoding cofilin and RFP (red) under separate CMV promoters. Phalloidin labeling (purple) and $\gamma$-actin-GFP fluorescence (green) are absent from the junction region in the infected cells. $\boldsymbol{B}$, Images of example cells in three separate utricles from adult $\gamma$-actin-GFP mice that were cultured for $96 \mathrm{~h}$ after infection with adenovirus encoding RFP (red) alone. Phalloidin labeling (purple) and $\gamma$-actin-GFP fluorescence (green) show that circumferential F-actin bands persist at the junction level in the infected cells.

to LatA-mediated disassembly (Fig. 9D,E). Although stability grows with age in all regions of the thickening actin bands, these results reveal that the F-actin that is near the junction membrane is likely to differ in its posttranslational modification or its associations with actin binding or capping proteins, so that it exhibits greater mobility than occurs in the more central regions of the bands (Fig. 9F).

\section{Stabilization parallels changes in the responses of SCs near dying HCs}

The postnatal changes in the F-actin bands occur in parallel with a deep decline in plasticity, raising the possibility that the development of these highly stabilized junctions and junctional cytoskeletons plays a role in limiting the plasticity of mammalian SCs and their capacity to form HCs. In many vertebrate inner ears, when HCs die, they are extruded from the epithelial cell layer and the neighboring SCs expand their apical processes to reseal the breach at the surface of the epithelium (Fig. 2A, arrows; Bredberg, 1968; Forge, 1985; Corwin, 1986; Cotanche, 1987; Corwin et al., 1989; Raphael and Altschuler, 1991; Raphael et al., 1993; Leonova

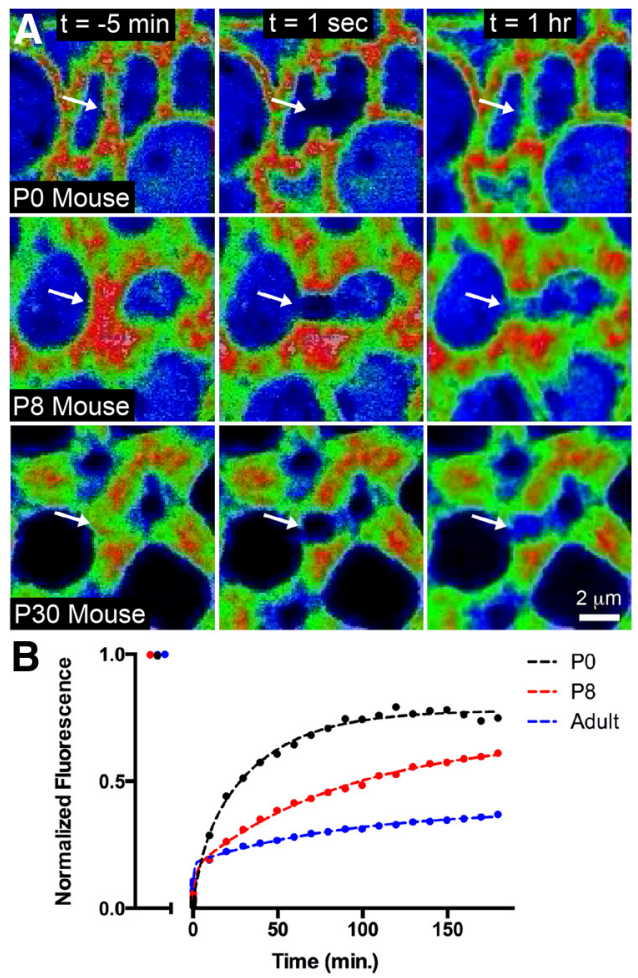

Figure 8. As mice mature postnatally, the actin in the circumferential bands of utricular $\mathrm{SC}$ becomes highly stabilized. $\boldsymbol{A}$, Confocal images captured at three time points during FRAP experiments in utricles from $\gamma$-actin-GFP mice at three ages. The photobleached regions (arrows) are shown $5 \mathrm{~min}$ before bleaching, $1 \mathrm{~s}$ after bleaching, and $1 \mathrm{~h}$ after. A rainbow lookup table was applied to the images to enhance contrast. Movie 1 shows dynamic comparisons of the FRAP results obtained in these experiments. $\boldsymbol{B}, \mathrm{A}$ graph showing the time course of mean normalized fluorescence recovery measured in $\mathrm{SC}$ actin bands at each age. Plotted lines are fits of two-phase exponential equations, which show that the rate of fluorescence recovery and the mobile fraction both decline as mice mature.

and Raphael, 1997; Hordichok and Steyger, 2007; Bird et al., 2010; Anttonen et al., 2012; Forge et al., 2013). Time-lapse recordings and treatments with LatA and CytoD have shown that F-actin polymerization plays a role in the expansion of the luminal surfaces of SCs that occurs in non-mammalian HC epithelia when HCs are lost (Figs. 2A, arrowheads, 6A, $B$, red arrows; Hordichok and Steyger, 2007; Bird et al., 2010).

To determine whether the stabilization of the junctional actin bands in mouse utricles coincides with changes in the way that SCs respond to cell loss, we made time-lapse microscopic recordings in utricles from $\gamma$-actin-GFP mice at P0 and $>$ P20. To increase the number of HCs that might die during the imaging period, we first cultured the utricles for $8 \mathrm{~h}$ in medium that contained $3 \mathrm{~mm}$ neomycin, because HCs are particularly susceptible to poisoning by aminoglycosides. Then we mounted the utricles (HCs facing down) under glass fibers that were glued to a glassbottom chamber containing DMEM/F-12 with $1 \%$ FBS. The dish was secured on the stage of a confocal microscope with an incubation unit that maintained the environment at $37^{\circ} \mathrm{C}, 5 \% \mathrm{CO}_{2}$ and 95\% humidity, and the microscope was controlled by a computer to automate the acquisition of $z$-stacks at regular intervals during the culture period. The time-lapse recordings we made in utricles from P0 mice suggest that epithelial resealing is driven by the contraction of a multicellular actin purse string that forms in the SCs surrounding each dying HC (Fig. 10 A, B, arrows; Movie 2 ). This mechanism appears analogous to processes that drive the extrusion of dying cells and the resealing of barrier integrity in 


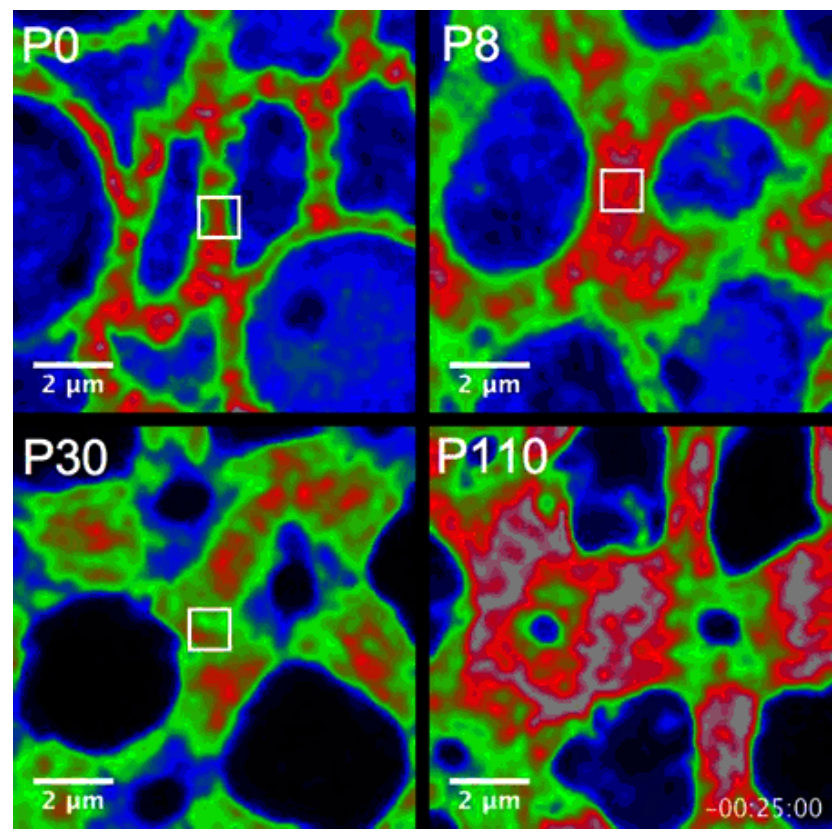

Movie 1. The rate and magnitude of FRAP in the circumferential F-actin bands of utricles from $\gamma$-actin-GFP mice slows and decreases substantially with age. Top and bottom left panels, Time-lapse recordings of photobleaching and fluorescence recovery of $1 \times 1 \mu \mathrm{m}$ square regions in the bands of $\mathrm{SC}$ from $\mathrm{PO}, \mathrm{P} 8$, and $\mathrm{P} 30$ utricles. A rainbow lookup table was applied to the movies to enhance contrast. White boxes show the location of the bleach region. Note the rapid recovery of fluorescence within the bleach region in $\mathrm{PO}$ mice compared with adults. Bottom right panel, Time-lapse recording of a line bleach of an AJR in a utricle from a P110 $\gamma$-actinGFP mouse shows that the fastest recovery occurs near the junctional membrane. The time shown at the bottom right applies to all panels and is displayed in hours:minutes:seconds. Before each bleach pulse, a stack of confocal images was acquired every 5 min for 25 min. A stack was acquired immediately after the bleach (00:00:00 in the movie) and then every $10 \mathrm{~min}$ thereafter. The movie shows a single confocal slice of the stack, which has been corrected for spatial drift.

other epithelia (Hudspeth, 1975; Rosenblatt et al., 2001; Jacinto et al., 2002; Wood et al., 2002; Bird et al., 2010). In most instances, purse-string contraction took $\sim 1 \mathrm{~h}$, and the forces exerted by the resealing process caused clear deformation and shape changes of all cells in the vicinity. It is notable that, in these young mouse utricles, SCs that were distant from the dying $\mathrm{HC}$ also changed shape as the immediately neighboring SCs formed and contracted a purse string, as though changes in mechanical tension were being transmitted through the epithelial sheet for distances of several cell diameters. After the contraction of the multicellular purse string reached completion, the lateral membranes of the SCs that had bordered the dying HC met near the center of the site previously occupied by the lost $\mathrm{HC}$, and new intercellular junctions were established and bracketed by new F-actin bands. When that occurred, the preexisting F-actin bands appeared to be left behind in approximately their original locations in the apical cytoplasm. Eventually, such preexisting bands broke down and disappeared (Movie 2).

Transient band remnants could be visualized within the cytoplasm of SCs around the point of purse-string closure (Movie 2). In fixed P0 utricles cultured for $8 \mathrm{~h}$ with $3 \mathrm{~mm}$ neomycin, immunolabeling with an antibody to the tight junction protein occludin showed larger than usual separations between the tight junction and such remnants of the preexisting circumferential F-actin bands in SCs neighboring dead or dying HCs (Fig. 10C, arrowheads). This indicates that the lateral membranes and tight junctions in these cells disassociated from the remnants of the preexisting actin band. It appears likely that these band remnants consist of the more stabilized population of actin filaments within the inner band regions, whereas the more dynamic F-actin that is located near the junctional membrane could contribute to the formation of the purse string and participate in closure. Alternatively, the F-actin purse string could develop de novo.

In contrast to the P0 utricles, SCs in utricles from $>$ P20 $\gamma$-actin-GFP mice failed to form clearly recognizable contractile "purse-string" structures, and the majority of the SCs in each image field appeared to remain static throughout the period of each recording (Movie 2). In these more mature utricles, the changes appeared to be restricted to two or three SCs at each site of cell loss. The responses of each of those cells either maintained or reestablished the apical integrity of the epithelium, and that was accompanied by the de novo formation of a new, thinner F-actin band that extended radially toward the center of the region occupied previously by the lost $\mathrm{HC}$ (Fig. 10D,E, arrows; Movie 2). The duration of this process in utricles from $>\mathrm{P} 20$ mice was more variable than the contractile events that occurred in $\mathrm{P} 0$ mouse utricles, taking from $\sim 1$ to $4 \mathrm{~h}$.

Other mature SCs that were in the vicinity of the resealing $\mathrm{HC}$ lesion remained nearly motionless and showed little deformation of their apical outlines. The difference between the dynamic movements and shape changes of the SCs in the vicinity of resealing $\mathrm{HC}$ lesions in the utricles from P0 and >P20 mice is evident in Movie 2. In the individual SCs that participated in the resealing process in utricles from $>$ P2 0 mice, the thick, preexisting F-actin bands were not pulled into the region occupied previously by the dying $\mathrm{HC}$; instead, they remained where they had been at the start of each recording. Such bands usually did not break down during the $12 \mathrm{~h}$ period of time-lapse recording after resealing was complete (Fig. 10F, arrowheads; Movie 2). Thus, stabilization of the circumferential F-actin bands in SCs of the mature mouse sensory epithelium may play a role in limiting the number of cells that are affected by dynamic changes in intraepithelial tension and other signals that emanate from a dying $\mathrm{HC}$ or a site of $\mathrm{HC}$ loss.

\section{Discussion}

We show here that the stability of an integral component of the junctional complex, the circumferential F-actin band, varies dramatically in vestibular SCs from different species. In mammals, its stability also changes as the ear matures postnatally and the actin bands grow to fill $\sim 90 \%$ of the apical cytoplasmic area in the average utricular SC of adult mice and humans. At the same time, vestibular epithelia in mammals lose their capacity for cell replacement and effective regeneration of lost HCs. Although our findings do not establish causality, they point out a potential link between junction stabilization and the unexplained restriction of cellular plasticity in mammalian HC epithelia. Time-lapse microscopy shows that this stabilization is accompanied by changes in SC responses to HC loss, which in young mice is followed by shape change and movement of many nearby SCs that form a multicellular, contractile F-actin purse string, but in adults evokes responses in fewer SCs that do not form purse strings. Our findings are consistent with recent evidence that indicates that changes in junction-associated proteins and the mechanical tension that is transmitted through junctions and their actin cytoskeletons play pivotal roles in regulating cellular quiescence and the dynamic matching of cell replacement to cell loss in epithelia (Boggiano and Fehon, 2012; Guillot and Lecuit, 2013). 

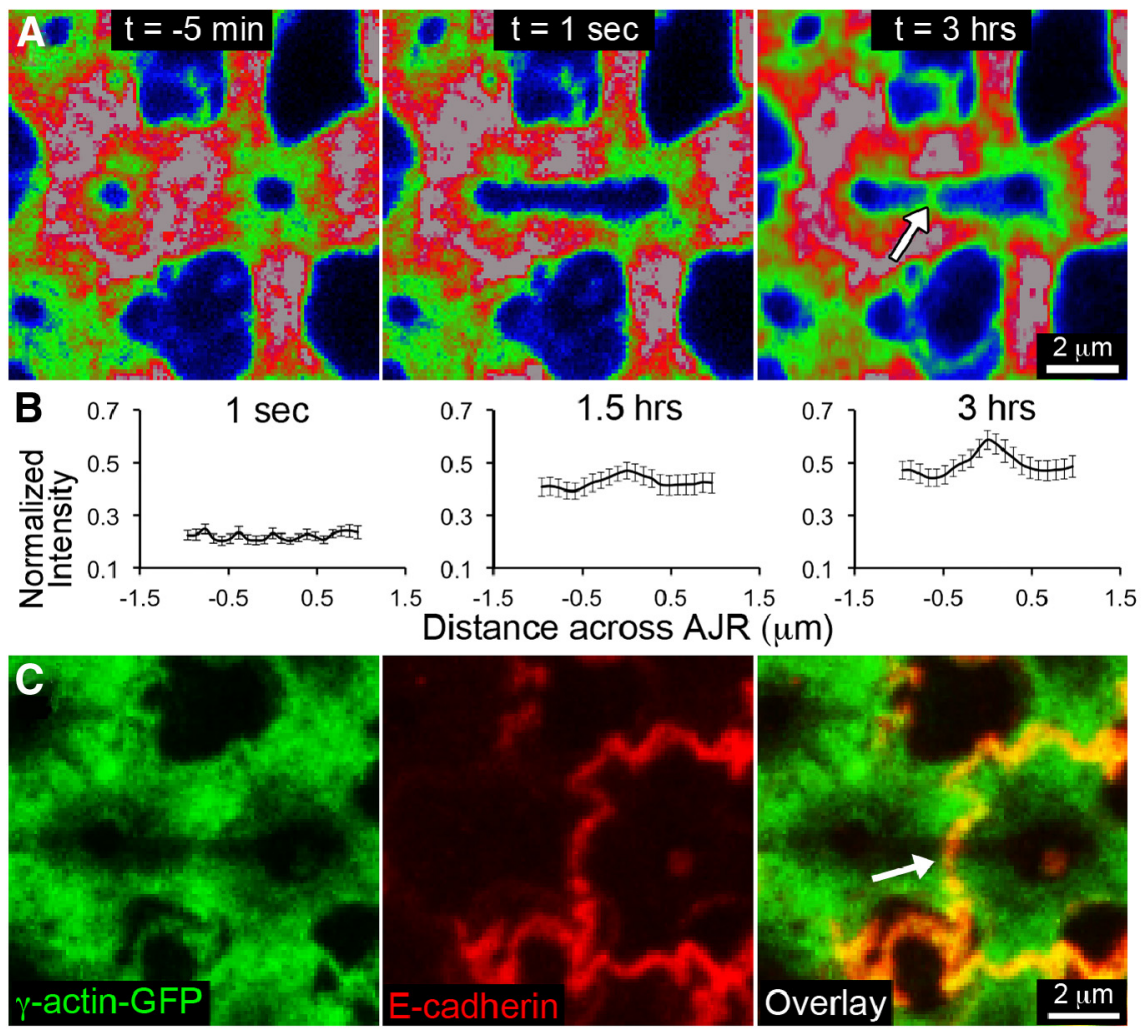

Distance across AJR $(\mu \mathrm{m})$
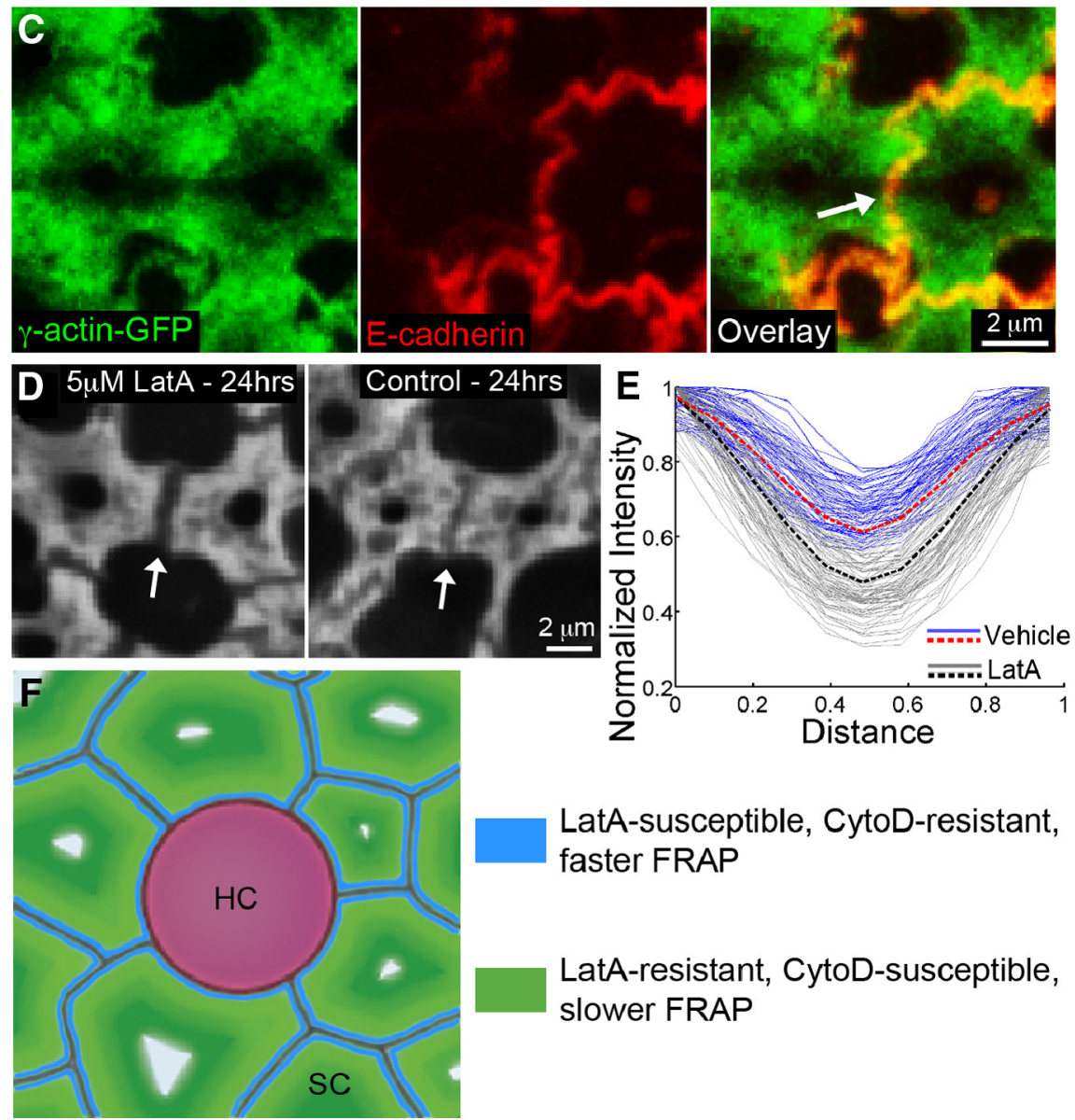

LatA-susceptible, CytoD-resistant, faster FRAP

\section{LatA-resistant, CytoD-susceptible,} slower FRAP

Figure 9. The actin near the junction membrane in the $\mathrm{SCS}$ of adult mouse utricles shows greater mobility than the actin in the other parts of the circumferential bands and greater susceptibility to disruption by LatA treatment. $\boldsymbol{A}$, Images from a FRAP experiment in which a 1-pixel-wide line was photobleached across the entire AJR (i.e., from the center of $1 \mathrm{SC}$ to the center of its neighbor). The photobleached region is shown 5 min before bleaching, $1 \mathrm{~s}$ after bleaching, and $3 \mathrm{~h}$ after. $\boldsymbol{B}$, Graphs show the normalized fluorescence intensity profiles averaged from 10 photobleached AJRs at $1 \mathrm{~s}, 1.5 \mathrm{~h}$, and $3 \mathrm{~h}$ time points after photobleaching. A peak emerges at the center of the AJR by $1.5 \mathrm{~h}$ and increases in magnitude by $3 \mathrm{~h}$, suggesting that actin is more mobile near the junction membrane. $C$, Image from a FRAP experiment in which a 1-pixel-wide line was photobleached across the entire $A J R$, and then utricles were cultured for $3 \mathrm{~h}$ and fixed and labeled with antibodies to the intercellular junction protein $\mathrm{E}$-cadherin (red; $n=2$ utricles). Arrow indicates the location of maximum recovery in the photobleached AJR, which colocalizes with the E-cadherin labeling at the intercellular junction (arrow). D, Zoomed regions of the images in Figure $2 A$ show AJRs of SCs in a utricle treated with $5 \mu \mathrm{m}$ LatA for $24 \mathrm{~h}$ (left) and one cultured as a vehicle control (right). Arrows point to the gap between the edges of the phalloidin-labeled bands nearest to the lateral membrane in adjacent SCS, which appeared to become wider in the LatAtreated utricles. $\boldsymbol{E}$, Graph shows plot of 100 line intensity profiles measured across the intercellular junction shared between SCS (i.e., the gap shown in $\boldsymbol{D}$ ) in utricles treated with $5 \mu \mathrm{m}$ LatA (gray lines) and vehicle alone (blue lines) for $24 \mathrm{~h}$. The mean width in the LatA-treated utricles (black dashed line) was $0.56 \pm 0.13 \mu \mathrm{m}$, which was significantly wider than the $0.44 \pm 0.13 \mu \mathrm{m}$ width
The circumferential F-actin bands become uniquely stabilized

Although maturation slows turnover of the F-actin that helps anchor membrane adhesion proteins at junctions, cytochalasin and latrunculin treatments cause disassembly of circumferential actin bands within 5-60 min in many epithelial cells in vitro and in intestinal epithelium, Sertoli cells, and Drosophila in vivo (Fig. 1; Madara et al., 1986; Weber et al., 1988; Stevenson and Begg, 1994; Adams et al., 1998; Braga et al., 1999; Vasioukhin et al., 2000; Ivanov et al., 2005; Yamada et al., 2005; Zhang et al., 2005; Pilot et al., 2006; Abe and Takeichi, 2008; Cavey et al., 2008; Yu et al., 2010; Huang et al., 2011; Tang and Brieher, 2012). However, LatA treatments took $12-24 \mathrm{~h}$ to cause notable effects on the bands in SCs from young mice and chickens, and CytoD failed to produce measurable effects even after $24 \mathrm{~h}$. The thick actin bands in adult mouse utricles showed even greater resistance to LatA-mediated depolymerization, and CytoD took $\sim 24$ h to cause substantial thinning. Such results suggested that circumferential F-actin in mammalian SCs becomes progressively stabilized with age, and our FRAP results supported that hypothesis by showing substantially lower $\gamma$-actin-GFP mobility within the bands in young mouse SCs compared with MDCK or Caco-2 cells (Yamada et al., 2005; Yu et al., 2010) and exceptionally high measures of junctional F-actin stability in the SCs of mature mouse utricles.

We reported recently that the vestibular SCs in adult Anole lizards, Anolis carolinensis, contain accumulations of $\mathrm{F}$-actin at their apical junctions that extend from the junctions in toward the center of the apical cytoplasm, like the actin bands in adult mammalian SCs (Burns et al., 2013). Although the actin bands in Anolis SCs are primarily unexplored, it is clear that they have a reticulated and porous organization that is distinctly different from the dense mesh of F-actin that grows inward from the intercellular junctions of vestibular SCs in mammals. Preliminary experiments suggest that Anolis SCs can reenter the cell cycle like SCs in other nonmammalian species, and it is tempting to speculate that the porous nature of their

\section{$\leftarrow$}

measured in the vehicle controls (red dashed line; $n=4$ utricles; $p=0.0001$, Student's $t$ test). $\boldsymbol{F}$, An illustration depicting the spatial relationships between regions in the thick F-actin bands in adult mice that show differences in F-actin dynamics. 
actin webs may permit severing proteins to penetrate and cause disassembly in response to injury to the $\mathrm{HC}$ epithelium. Future investigations are needed to assess actin web stability in Anolis SCs and determine how readily such SCs proliferate and whether that can lead to the regeneration of HCs as occurs in birds and other nonmammals, in which the junctional actin bands of SCs remain thin throughout life.

\section{Stabilization of circumferential F-actin bands may directly limit SC proliferation}

In the days and weeks after birth, F-actin accumulates and stabilizes at mammalian SC junctions, and SCs appear to develop high internal resistance to shape change (Davies et al., 2007; Meyers and Corwin, 2007; Collado et al., 2011a). Over the same period, plasticity declines and SCs become refractory to damage-induced cell cycle reentry that is common to the $\mathrm{HC}$ regeneration responses in non-mammals (Ruben, 1967; Gu et al., 1997, 2007; Lu and Corwin, 2008; Meyers et al., 2009; Burns et al., 2012a,b).

How might stabilization of the thick bands of junctional F-actin limit plasticity? F-actin stabilization could immobilize adhesion proteins, such as E-cadherin, as it does in other epithelia (Cavey and Lecuit, 2009). E-cadherin binds $\alpha$ - and $\beta$-catenin at the junction (Gottardi and Gumbiner, 2004; Harris and Peifer, 2005), and recent evidence indicates that the E-cadherin/catenin complex functions as an upstream signal that regulates the phosphorylation of YAP (Yes-associated protein), a key transcription coactivator in the proliferation-inhibiting Hippo signaling pathway (Kim et al., 2011). Loss of homophilic E-cadherin ligation in epithelial cells allows dephosphorylation of YAP, which prevents its nuclear translocation and interactions with TEA domain family transcription factors that promote proliferation and survival (Kim et al., 2011; Schlegelmilch et al., 2011; Silvis et al., 2011; Boggiano and Fehon, 2012; Ramos and Camargo, 2012). Consistent with the hypothesis that homophilic ligation of E-cadherin could act to inhibit proliferation in mouse SCs, E-cadherin increases at least sixfold at their junctions during the period when F-actin bands become stabilized (Collado et al., 2011b; Burns et al., 2013). However, E-cadherin is absent or expressed at low levels at vestibular SC junctions in fish, amphibians, turtles, and birds, which all produce or regenerate $\mathrm{HCs}$ throughout life (Warchol, 2007; Collado et al., 2011b; Burns et al., 2013). In developing mouse ears and damaged avian ears, S-phase labeling and RNA sequencing data also support a role for $\beta$-catenin in regulating proliferation (Hawkins et al., 2003, 2007; Alvarado et al., 2011; Jacques et al., 2012; Shi et al., 2013). Stabilization of F-actin also holds the potential to inhibit proliferation more directly, because the massive accumulation of stabilized F-actin that occurs at the junctions between mouse SCs could lead to decreases in globular $\beta$-actin in the nucleus, which
Po Mouse

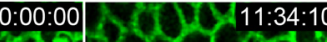

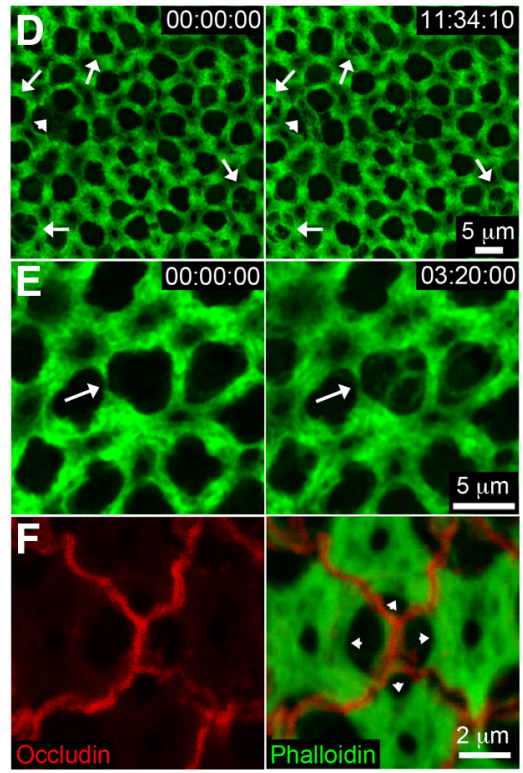

\section{Adult Mouse}

Figure 10. Images from a series of time-lapse recordings of SC responses to antibiotic-induced HC death show that the SCs in utricles from neonatal mice move as a sheet and undergo dynamic shape changes as they reseal lesions in the epithelium and havembled completely. C, Confocal images of utricles from P0 mice that were cultured with 3 mm neomycin for $8 \mathrm{~h}$ and between the cells. D, F, Same experimental and imaging conditions as $\boldsymbol{A}$-C but for utricles from adult mice in which only the

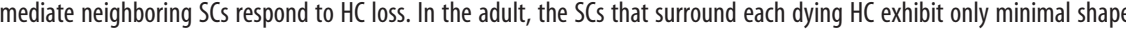
most reathe intact in most responding adult SCS after resealing has occurred. Arrowhead in $\boldsymbol{D}$ indicates an F-actin band that appeared to disassemble and then reassemble. See also Movie 2. D, P30 mouse; $\boldsymbol{E}$, P156 mouse; $\boldsymbol{F}$, P80 mouse.

has been shown to control proliferative quiescence in mammary epithelia (Spencer et al., 2011).

In addition, F-actin stabilization is likely to increase SC stiffness and limit the intercellular spread of changes in mechanical tension that have been linked to increased proliferation in epithelia (Ingber, 2008; Guillot and Lecuit, 2013). In the neonatal organ of Corti, contractile networks of nonmuscle myosin II are periodically distributed along the thin actin bands on both sides of the junctions between nonsensory inner sulcus cells (Ebrahim et al., 2013). Such contractility is likely to be limited by the growth of the thick, highly stabilized F-actin bands that develop in the apical cytoplasm of mature SCs, consistent with the minimal spatial spread and magnitude of the changes in SC shape we observed during $\mathrm{HC}$ loss in utricles from adult mice (Fig. 10; Movie 2).

\section{Stabilization differs near the junction membrane}

Actin filaments with faster turnover and increased mobility could segregate near the lateral membrane to support more rapid remodeling of apical SC junctions (Fig. 9; Georgiou et al., 2008; Harris and Tepass, 2008; Shen et al., 2008; de Beco et al., 2009). However, the rate and extent of junctional remodeling in adult SCs may be slow compared with young mouse SCs because F-actin in this region also becomes less mobile with age. This more static apical junction in adults may permit alterations for 


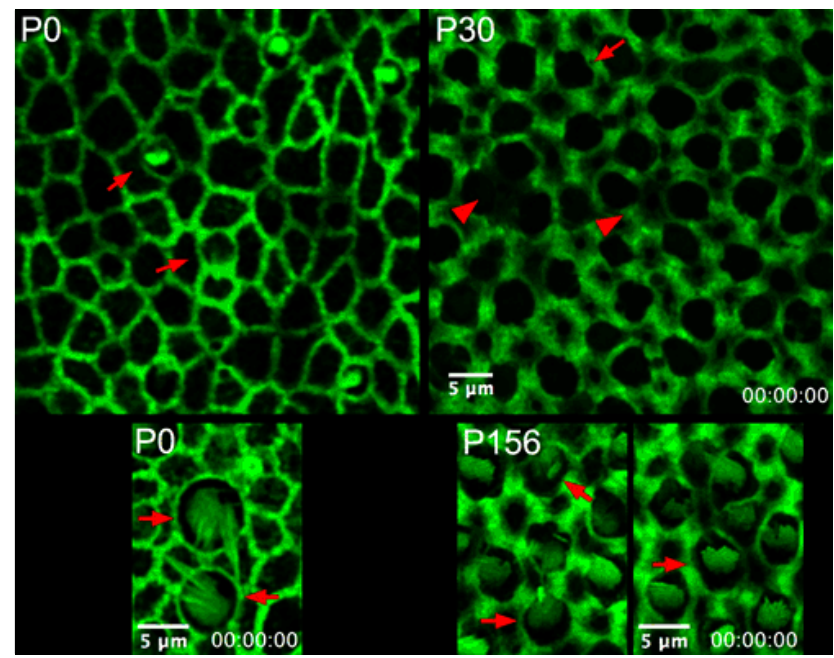

Movie 2. SCs in utricles from neonatal mice organize contractile multicellular F-actin purse strings and dynamically change shape as they reseal the epithelium around sites of dying $\mathrm{HCS}$, but the SCs in adult utricles appear resistant to deformation and do not form detectable purse strings. Shown are low-resolution (top) and high-resolution (bottom) time-lapse recordings of utricles from newborn and adult $\gamma$-actin-GFP mice after they were treated with 3 mм neomycin for $8 \mathrm{~h}$ to kill HCs. Arrows point to locations in which HCs die and the surrounding SCs respond and reseal the epithelium. Arrowheads in recordings of adult tissue point to F-actin bands that appear to disassemble and reassemble later in the time lapse. In the P0 sensory epithelium, the repair process is rapid and involves the formation of a multicellular contractile actin purse string and dynamic shape changes of the $\mathrm{SC}$ s surrounding the dying $\mathrm{HCs}$ (arrows). In the adult sensory epithelia, fewer SCs respond and epithelial resealing is more variable. Some sites of HC loss appear to be sealed within $1 \mathrm{~h}$ (arrow in right P156 panel). Others are repaired over several hours, with radial bands of F-actin slowly developing at the site of $\mathrm{HC}$ death (bottom arrow in left P156 panel). Some apparent vacancies in the epithelium were left at sites of dying HCs and did not appear to be repaired during the $9 \mathrm{~h}$ time-lapse period. Time is shown in hours:minutes: seconds. The movies have been corrected for spatial drift.

only the most essential processes that are necessary for cell function and survival.

For example, age-related stabilization of the more dynamic population of F-actin near the junctional membrane may restrict the mobility and deformability of adult SCs when they attempt to repair the epithelium after HC loss (Fig. 10; Movie 2). In Drosophila embryos, the formation of an F-actin purse string appears to limit lamellipodial movement at the leading edge during dorsal closure (Jacinto et al., 2002; Wood et al., 2002), and the responses of SCs in adult utricles somewhat resemble lamellipodial movement. We suspect that the crosslinking of F-actin near adult SC junctions may be dynamic enough for epithelia to reseal but does not allow for the formation of a multicellular contractile purse string. It is plausible that the thick and highly stabilized F-actin bands in the SCs of mammals evolved because selective advantages from increased sensory epithelium rigidity provided greater mechanoreceptor sensitivity and stimulus fidelity that counterbalanced the disadvantages from limited HC regeneration capabilities (Burns et al., 2008). The increased junctional stability that develops in maturing mammalian SCs also is hypothesized to play a role in limiting rearrangements of SCs and HCs that would disturb the precise planar polarity required for sensory function (Copley et al., 2013).

\section{A model for cytoskeletal changes that limit plasticity}

Our data support a model wherein the circumferential actin bands at the intercellular junctions of SCs grow in thickness and become highly stabilized through their interactions with actin crosslinking proteins as mammalian ears mature postnatally. The stabilization, in turn, likely increases intracellular stiffness and restricts how far mechanical tension changes are transmitted through the stout intercellular web formed by the junctions and cytoskeletal networks beneath the surface of vestibular epithelia in adult mammals. It remains to be formally determined whether the spatial restriction of tension changes contributes to the contemporaneous decrease in the spatial spread of SC responses when neighboring $\mathrm{HCs}$ die or whether the stability of the actin bands contributes to cell-autonomous changes that limit SC shape changes and proliferation.

Unfortunately, global F-actin disruption is not useful for testing whether the actin bands in mature mammalian SCs actually help to limit plasticity and regenerative capabilities, because F-actin plays vital roles in cell cycle progression. Therefore, tissue-specific knockdown of actin crosslinking proteins that stabilize the filaments within these unique junctional structures will be required to determine whether and to what degree they contribute to the vulnerability of the mammalian ear to permanent $\mathrm{HC}$ deficits.

\section{Notes}

This article has an associated cover video.

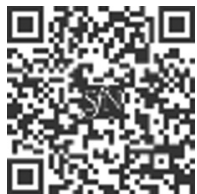

\section{References}

Abe K, Takeichi M (2008) EPLIN mediates linkage of the cadherin catenin complex to F-actin and stabilizes the circumferential actin belt. Proc Natl Acad Sci U S A 105:13-19. CrossRef Medline

Adams CL, Chen YT, Smith SJ, Nelson WJ (1998) Mechanisms of epithelial cell-cell adhesion and cell compaction revealed by high-resolution tracking of E-cadherin-green fluorescent protein. J Cell Biol 142:1105-1119. CrossRef Medline

Alvarado DM, Hawkins RD, Bashiardes S, Veile RA, Ku YC, Powder KE, Spriggs MK, Speck JD, Warchol ME, Lovett M (2011) An RNA interference-based screen of transcription factor genes identifies pathways necessary for sensory regeneration in the avian inner ear. J Neurosci 31:4535-4543. CrossRef Medline

Amato PA, Taylor DL (1986) Probing the mechanism of incorporation of fluorescently labeled actin into stress fibers. J Cell Biol 102:1074-1084. CrossRef Medline

Anttonen T, Kirjavainen A, Belevich I, Laos M, Richardson WD, Jokitalo E, Brakebusch C, Pirvola U (2012) Cdc42-dependent structural development of auditory supporting cells is required for wound healing at adulthood. Sci Rep 2:978. CrossRef Medline

Bamburg JR, Wiggan OP (2002) ADF/cofilin and actin dynamics in disease. Trends Cell Biol 12:598-605. CrossRef Medline

Bird JE, Daudet N, Warchol ME, Gale JE (2010) Supporting cells eliminate dying sensory hair cells to maintain epithelial integrity in the avian inner ear. J Neurosci 30:12545-12556. CrossRef Medline

Boggiano JC, Fehon RG (2012) Growth control by committee: intercellular junctions, cell polarity, and the cytoskeleton regulate Hippo signaling. Dev Cell 22:695-702. CrossRef Medline

Braga VM, Del Maschio A, Machesky L, Dejana E (1999) Regulation of cadherin function by Rho and Rac: modulation by junction maturation and cellular context. Mol Biol Cell 10:9-22. CrossRef Medline

Bredberg G (1968) Cellular pattern and nerve supply of the human organ of Corti. Acta Otolaryngol [Suppl] 236:1+. Medline

Brigande JV, Heller S (2009) Quo vadis, hair cell regeneration? Nat Neurosci 12:679-685. CrossRef Medline

Burns JC, Corwin JT (2013) A historical to present-day account of efforts to answer the question: "what puts the brakes on mammalian hair cell regeneration?”. Hear Res 297:52-67. CrossRef Medline

Burns JC, Christophel JJ, Collado MS, Magnus C, Carfrae M, Corwin JT 
(2008) Reinforcement of cell junctions correlates with the absence of hair cell regeneration in mammals and its occurrence in birds. J Comp Neurol [Erratum (2011) 519:3816] 511:396-414. CrossRef Medline

Burns JC, Cox BC, Thiede BR, Zuo J, Corwin JT (2012a) In vivo proliferative regeneration of balance hair cells in newborn mice. J Neurosci 32:65706577. CrossRef Medline

Burns JC, On D, Baker W, Collado MS, Corwin JT (2012b) Over half the hair cells in the mouse utricle first appear after birth, with significant numbers originating from early postnatal mitotic production in peripheral and striolar growth zones. J Assoc Res Otolaryngol 13:609-627. CrossRef Medline

Burns JC, Collado MS, Oliver ER, Corwin JT (2013) Specializations of intercellular junctions are associated with the presence and absence of hair cell regeneration in ears from six vertebrate classes. J Comp Neurol 521: 1430-1448. CrossRef Medline

Campbell JJ, Knight MM (2007) An improved confocal FRAP technique for the measurement of long-term actin dynamics in individual stress fibers. Microsc Res Tech 70:1034-1040. CrossRef Medline

Cavey M, Lecuit T (2009) Molecular bases of cell-cell junctions stability and dynamics. Cold Spring Harb Perspect Biol 1:a002998. CrossRef Medline

Cavey M, Rauzi M, Lenne PF, Lecuit T (2008) A two-tiered mechanism for stabilization and immobilization of E-cadherin. Nature 453:751-756. CrossRef Medline

Collado MS, Burns JC, Meyers JR, Corwin JT (2011a) Variations in shapesensitive restriction points mirror differences in the regeneration capacities of avian and mammalian ears. PLoS One 6:e23861 CrossRef Medline

Collado MS, Thiede BR, Baker W, Askew C, Igbani LM, Corwin JT (2011b) The postnatal accumulation of junctional E-cadherin is inversely correlated with the capacity for supporting cells to convert directly into sensory hair cells in mammalian balance organs. J Neurosci 31:11855-11866. CrossRef Medline

Copley CO, Duncan JS, Liu C, Cheng H, Deans MR (2013) Postnatal refinement of auditory hair cell planar polarity deficits occurs in the absence of vangl2. J Neurosci 33:14001-14016. CrossRef Medline

Corwin JT (1986) Regeneration and self-repair in hair cell epithelia: Experimental evaluation of capacities and limitations. In: Biology of change in otolaryngology (Ruben RJ, Van de Water TR, Rubel EW, eds), pp 291304. New York: Elsevier.

Corwin JT, Balak KJ, Borden PC (1989) Cellular events underlying the regenerative replacement of lateral line sensory epithelia in amphibians. In: The mechanosensory lateral line: neurobiolgy and evolution (Coombs S, Gorner P, Munz H, eds), pp 161-183. New York: Springer.

Cotanche DA (1987) Regeneration of hair cell stereociliary bundles in the chick cochlea following severe acoustic trauma. Hear Res 30:181-195. CrossRef Medline

Davies D, Magnus C, Corwin JT (2007) Developmental changes in cellextracellular matrix interactions limit proliferation in the mammalian inner ear. Eur J Neurosci 25:985-998. CrossRef Medline

Deans MR (2013) A balance of form and function: planar polarity and development of the vestibular maculae. Semin Cell Dev Biol 24:490-498. CrossRef Medline

de Beco S, Gueudry C, Amblard F, Coscoy S (2009) Endocytosis is required for E-cadherin redistribution at mature adherens junctions. Proc Natl Acad Sci U S A 106:7010-7015. CrossRef Medline

Ebrahim S, Fujita T, Millis BA, Kozin E, Ma X, Kawamoto S, Baird MA, Davidson M, Yonemura S, Hisa Y, Conti MA, Adelstein RS, Sakaguchi H, Kachar B (2013) NMII forms a contractile transcellular sarcomeric network to regulate apical cell junctions and tissue geometry. Curr Biol 23: 731-736. CrossRef Medline

Fischer M, Kaech S, Knutti D, Matus A (1998) Rapid actin-based plasticity in dendritic spines. Neuron 20:847-854. CrossRef Medline

Fischer M, Kaech S, Wagner U, Brinkhaus H, Matus A (2000) Glutamate receptors regulate actin-based plasticity in dendritic spines. Nat Neurosci 3:887-894. CrossRef Medline

Forge A (1985) Outer hair cell loss and supporting cell expansion following chronic gentamicin treatment. Hear Res 19:171-182. CrossRef Medline

Forge A, Jagger DJ, Kelly JJ, Taylor RR (2013) Connexin30-mediated intercellular communication plays an essential role in epithelial repair in the cochlea. J Cell Sci 126:1703-1712. CrossRef Medline

Georgiou M, Marinari E, Burden J, Baum B (2008) Cdc42, Par6, and aPKC regulate Arp2/3-mediated endocytosis to control local adherens junction stability. Curr Biol 18:1631-1638. CrossRef Medline
Golub JS, Tong L, Ngyuen TB, Hume CR, Palmiter RD, Rubel EW, Stone JS (2012) Hair cell replacement in adult mouse utricles after targeted ablation of hair cells with diphtheria toxin. J Neurosci 32:15093-15105. CrossRef Medline

Gottardi CJ, Gumbiner BM (2004) Distinct molecular forms of betacatenin are targeted to adhesive or transcriptional complexes. J Cell Biol 167:339-349. CrossRef Medline

Groves AK, Fekete DM (2012) Shaping sound in space: the regulation of inner ear patterning. Development 139:245-257. CrossRef Medline

Gu R, Marchionni M, Corwin JT (1997) Age-related decreases in proliferation within isolated mammalian vestibular epithelia cultured in control and glial growth factor 2 medium. Assoc Res Otolaryngol Abstr 20:98.

Gu R, Montcouquiol M, Marchionni M, Corwin JT (2007) Proliferative responses to growth factors decline rapidly during postnatal maturation of mammalian hair cell epithelia. Eur J Neurosci 25:1363-1372. CrossRef Medline

Guillot C, Lecuit T (2013) Mechanics of epithelial tissue homeostasis and morphogenesis. Science 340:1185-1189. CrossRef Medline

Harris KP, Tepass U (2008) Cdc42 and Par proteins stabilize dynamic adherens junctions in the Drosophila neuroectoderm through regulation of apical endocytosis. J Cell Biol 183:1129-1143. CrossRef Medline

Harris TJ, Peifer M (2005) Decisions, decisions: beta-catenin chooses between adhesion and transcription. Trends Cell Biol 15:234-237. CrossRef Medline

Hawkins RD, Bashiardes S, Helms CA, Hu L, Saccone NL, Warchol ME, Lovett M (2003) Gene expression differences in quiescent versus regenerating hair cells of avian sensory epithelia: implications for human hearing and balance disorders. Hum Mol Genet 12:1261-1272. CrossRef Medline

Hawkins RD, Bashiardes S, Powder KE, Sajan SA, Bhonagiri V, Alvarado DM, Speck J, Warchol ME, Lovett M (2007) Large scale gene expression profiles of regenerating inner ear sensory epithelia. PLoS One 2:e525. CrossRef Medline

Hordichok AJ, Steyger PS (2007) Closure of supporting cell scar formations requires dynamic actin mechanisms. Hear Res 232:1-19. CrossRef Medline

Huang J, Huang L, Chen YJ, Austin E, Devor CE, Roegiers F, Hong Y (2011) Differential regulation of adherens junction dynamics during apicalbasal polarization. J Cell Sci 124:4001-4013. CrossRef Medline

Hudspeth AJ (1975) Establishment of tight junctions between epithelial cells. Proc Natl Acad Sci U S A 72:2711-2713. CrossRef Medline

Ingber DE (2008) Tensegrity-based mechanosensing from macro to micro. Prog Biophys Mol Biol 97:163-179. CrossRef Medline

Ivanov AI, Hunt D, Utech M, Nusrat A, Parkos CA (2005) Differential roles for actin polymerization and a myosin II motor in assembly of the epithelial apical junctional complex. Mol Biol Cell 16:2636-2650. CrossRef Medline

Jacinto A, Wood W, Woolner S, Hiley C, Turner L, Wilson C, Martinez-Arias A, Martin P (2002) Dynamic analysis of actin cable function during Drosophila dorsal closure. Curr Biol 12:1245-1250. CrossRef Medline

Jacques BE, Puligilla C, Weichert RM, Ferrer-Vaquer A, Hadjantonakis AK, Kelley MW, Dabdoub A (2012) A dual function for canonical Wnt/betacatenin signaling in the developing mammalian cochlea. Development 139:4395-4404. CrossRef Medline

Kelly MC, Chang Q, Pan A, Lin X, Chen P (2012) Atoh1 directs the formation of sensory mosaics and induces cell proliferation in the postnatal mammalian cochlea in vivo. J Neurosci 32:6699-6710. CrossRef Medline

Kim NG, Koh E, Chen X, Gumbiner BM (2011) E-cadherin mediates contact inhibition of proliferation through Hippo signaling-pathway components. Proc Natl Acad Sci U S A 108:11930-11935. CrossRef Medline

Leonova EV, Raphael Y (1997) Organization of cell junctions and cytoskeleton in the reticular lamina in normal and ototoxically damaged organ of Corti. Hear Res 113:14-28. CrossRef Medline

Lippincott-Schwartz J, Snapp E, Kenworthy A (2001) Studying protein dynamics in living cells. Nat Rev Mol Cell Biol 2:444-456. CrossRef Medline

Lippincott-Schwartz J, Altan-Bonnet N, Patterson GH (2003) Photobleaching and photoactivation: following protein dynamics in living cells. Nat Cell Biol Suppl:S7-S14. Medline

Liu Z, Dearman JA, Cox BC, Walters BJ, Zhang L, Ayrault O, Zindy F, Gan L, Roussel MF, Zuo J (2012) Age-dependent in vivo conversion of mouse cochlear pillar and deiters' cells to immature hair cells by atoh1 ectopic expression. J Neurosci 32:6600-6610. CrossRef Medline 
Lu Z, Corwin JT (2008) The influence of glycogen synthase kinase 3 in limiting cell addition in the mammalian ear. Dev Neurobiol 68:1059-1075. CrossRef Medline

Madara JL, Barenberg D, Carlson S (1986) Effects of cytochalasin D on occluding junctions of intestinal absorptive cells: further evidence that the cytoskeleton may influence paracellular permeability and junctional charge selectivity. J Cell Biol 102:2125-2136. CrossRef Medline

Mallavarapu A, Mitchison T (1999) Regulated actin cytoskeleton assembly at filopodium tips controls their extension and retraction. J Cell Biol 146:1097-1106. CrossRef Medline

McGrath JL, Hartwig JH, Tardy Y, Dewey CF Jr (1998a) Measuring actin dynamics in endothelial cells. Microsc Res Tech 43:385-394. CrossRef Medline

McGrath JL, Tardy Y, Dewey CF Jr, Meister JJ, Hartwig JH (1998b) Simultaneous measurements of actin filament turnover, filament fraction, and monomer diffusion in endothelial cells. Biophys J 75:2070-2078. CrossRef Medline

Meng W, Takeichi M (2009) Adherens junction: molecular architecture and regulation. Cold Spring Harb Perspect Biol 1:a002899. CrossRef Medline

Meyers JR, Corwin JT (2007) Shape change controls supporting cell proliferation in lesioned mammalian balance epithelium. J Neurosci 27:43134325. CrossRef Medline

Meyers JR, Hu Z, Lu Z, Corwin JT (2009) Hair cell regeneration. In: Encyclopedia of neuroscience (Squire LR, ed), pp 1005-1013. Oxford, UK: Academic.

Miyoshi J, Takai Y (2008) Structural and functional associations of apical junctions with cytoskeleton. Biochim Biophys Acta 1778:670-691. CrossRef Medline

Nishida E, Iida K, Yonezawa N, Koyasu S, Yahara I, Sakai H (1987) Cofilin is a component of intranuclear and cytoplasmic actin rods induced in cultured cells. Proc Natl Acad Sci U S A 84:5262-5266. CrossRef Medline

Oshima K, Grimm CM, Corrales CE, Senn P, Martinez Monedero R, Géléoc GS, Edge A, Holt JR, Heller S (2007) Differential distribution of stem cells in the auditory and vestibular organs of the inner ear. J Assoc Res Otolaryngol 8:18-31. CrossRef Medline

Phair RD, Gorski SA, Misteli T (2004) Measurement of dynamic protein binding to chromatin in vivo, using photobleaching microscopy. Methods Enzymol 375:393-414. Medline

Pilot F, Philippe JM, Lemmers C, Lecuit T (2006) Spatial control of actin organization at adherens junctions by a synaptotagmin-like protein Btsz. Nature 442:580-584. CrossRef Medline

Quinlan MP, Hyatt JL (1999) Establishment of the circumferential actin filament network is a prerequisite for localization of the cadherin-catenin complex in epithelial cells. Cell Growth Differ 10:839-854. Medline

Ramos A, Camargo FD (2012) The Hippo signaling pathway and stem cell biology. Trends Cell Biol 22:339-346. CrossRef Medline

Raphael Y, Altschuler RA (1991) Scar formation after drug-induced cochlear insult. Hear Res 51:173-183. CrossRef Medline

Raphael Y, Athey BD, Wang Y, Hawkins JE Jr (1993) Structure of the reticular lamina and repair after noise injury. Rev Laryngol Otol Rhinol (Bord) 114:171-175. Medline

Rosenblatt J, Raff MC, Cramer LP (2001) An epithelial cell destined for apoptosis signals its neighbors to extrude it by an actin- and myosindependent mechanism. Curr Biol 11:1847-1857. CrossRef Medline

Rosin-Arbesfeld R, Ihrke G, Bienz M (2001) Actin-dependent membrane association of the APC tumour suppressor in polarized mammalian epithelial cells. EMBO J 20:5929-5939. CrossRef Medline

Ruben RJ (1967) Development of the inner ear of the mouse: a radioautographic study of terminal mitoses. Acta Otolaryngol [Suppl] 220:1-44. Medline

Sarmiere PD, Bamburg JR (2004) Regulation of the neuronal actin cytoskeleton by ADF/cofilin. J Neurobiol 58:103-117. CrossRef Medline

Schlegelmilch K, Mohseni M, Kirak O, Pruszak J, Rodriguez JR, Zhou D, Kreger BT, Vasioukhin V, Avruch J, Brummelkamp TR, Camargo FD (2011) Yap1 acts downstream of alpha-catenin to control epidermal proliferation. Cell 144:782-795. CrossRef Medline
Shen L, Weber CR, Turner JR (2008) The tight junction protein complex undergoes rapid and continuous molecular remodeling at steady state. J Cell Biol 181:683-695. CrossRef Medline

Shi F, Hu L, Edge AS (2013) Generation of hair cells in neonatal mice by beta-catenin overexpression in Lgr5-positive cochlear progenitors. Proc Natl Acad Sci U S A 110:13851-13856. CrossRef Medline

Silvis MR, Kreger BT, Lien WH, Klezovitch O, Rudakova GM, Camargo FD, Lantz DM, Seykora JT, Vasioukhin V (2011) alpha-catenin is a tumor suppressor that controls cell accumulation by regulating the localization and activity of the transcriptional coactivator Yap1. Sci Signal 4:ra33. CrossRef Medline

Song L, Hennink EJ, Young IT, Tanke HJ (1995) Photobleaching kinetics of fluorescein in quantitative fluorescence microscopy. Biophys J 68:2588 2600. CrossRef Medline

Spencer VA, Costes S, Inman JL, Xu R, Chen J, Hendzel MJ, Bissell MJ (2011) Depletion of nuclear actin is a key mediator of quiescence in epithelial cells. J Cell Sci 124:123-132. CrossRef Medline

Stauffer EA, Holt JR (2007) Sensory transduction and adaptation in inner and outer hair cells of the mouse auditory system. J Neurophysiol 98: 3360-3369. CrossRef Medline

Stevenson BR, Begg DA (1994) Concentration-dependent effects of cytochalasin D on tight junctions and actin filaments in MDCK epithelial cells. J Cell Sci 107:367-375. Medline

Tang VW, Brieher WM (2012) alpha-Actinin-4/FSGS1 is required for Arp2/ 3 -dependent actin assembly at the adherens junction. J Cell Biol 196:115130. CrossRef Medline

Tardy Y, McGrath JL, Hartwig JH, Dewey CF (1995) Interpreting photoactivated fluorescence microscopy measurements of steady-state actin dynamics. Biophys J 69:1674-1682. CrossRef Medline

Vasioukhin V, Bauer C, Yin M, Fuchs E (2000) Directed actin polymerization is the driving force for epithelial cell-cell adhesion. Cell 100:209-219. CrossRef Medline

Warchol ME (2007) Characterization of supporting cell phenotype in the avian inner ear: implications for sensory regeneration. Hear Res 227:1118. CrossRef Medline

Warchol ME (2011) Sensory regeneration in the vertebrate inner ear: differences at the levels of cells and species. Hear Res 273:72-79. CrossRef Medline

Weber JE, Turner TT, Tung KS, Russell LD (1988) Effects of cytochalasin D on the integrity of the Sertoli cell (blood-testis) barrier. Am J Anat 182: 130-147. CrossRef Medline

Wood W, Jacinto A, Grose R, Woolner S, Gale J, Wilson C, Martin P (2002) Wound healing recapitulates morphogenesis in Drosophila embryos. Nat Cell Biol 4:907-912. CrossRef Medline

Yamada A, Irie K, Fukuhara A, Ooshio T, Takai Y (2004) Requirement of the actin cytoskeleton for the association of nectins with other cell adhesion molecules at adherens and tight junctions in MDCK cells. Genes Cells 9:843-855. CrossRef Medline

Yamada S, Pokutta S, Drees F, Weis WI, Nelson WJ (2005) Deconstructing the cadherin-catenin-actin complex. Cell 123:889-901. CrossRef Medline

Yu D, Marchiando AM, Weber CR, Raleigh DR, Wang Y, Shen L, Turner JR (2010) MLCK-dependent exchange and actin binding region-dependent anchoring of ZO-1 regulate tight junction barrier function. Proc Natl Acad Sci U S A 107:8237-8241. CrossRef Medline

Zhang DS, Piazza V, Perrin BJ, Rzadzinska AK, Poczatek JC, Wang M, Prosser HM, Ervasti JM, Corey DP, Lechene CP (2012) Multi-isotope imaging mass spectrometry reveals slow protein turnover in hair-cell stereocilia. Nature 481:520-524. CrossRef Medline

Zhang J, Betson M, Erasmus J, Zeikos K, Bailly M, Cramer LP, Braga VM (2005) Actin at cell-cell junctions is composed of two dynamic and functional populations. J Cell Sci 118:5549-5562. CrossRef Medline

Zheng CY, Petralia RS, Wang YX, Kachar B (2011) Fluorescence recovery after photobleaching (FRAP) of fluorescence tagged proteins in dendritic spines of cultured hippocampal neurons. J Vis Exp pii:2568. CrossRef Medline 